Accepted refereed manuscript of: Hodgson ID, Redpath SM, Fischer A \& Young J (2019) Who knows best? Understanding the use of research-

\title{
Who knows best? Understanding the use of research-based knowledge in conservation conflicts
}

Hodgson, I.D., Redpath, S.M., Fischer, A., Young, J.C.

Highlights

- Research-based knowledge has an important role in conservation conflicts

- Analysis showed evidence of conceptual and strategic knowledge use

- Research was used to legitimise or challenge the 'status quo'

- Interpretation of research-based knowledge could reflect and reinforce different value systems

- Knowledge use can promote polarisation of views between stakeholder groups

\section{Abstract}

The way in which research-based knowledge is used, interpreted and communicated by different actors can influence the dynamics of conservation conflicts. The conflict that occurs between grouse shooting interests and the conservation of birds of prey in Scotland is notoriously complex, involving multiple actors at multiple levels, and shaped by the values and world views of these actors. This paper explores how research-based knowledge is used in the debate by six key organisations, and looks to understand the drivers that may influence knowledge use and interpretation in this, and other, cases of conservation conflict

Research was used to both legitimise and reinforce certain world views, and also to support associated political actions that would cause these to become reality. Actors offered divergent interpretations of the same piece of research, emphasising different findings and outcomes. Research-based knowledge was thus employed by actors to support or counter the 'status quo', and challenge other claims that clashed with their own values. Although the intention of such knowledge use is unclear, the selective reconstruction of research by actors could stem from, and reiterate, divergent value systems. This may pose significant challenges to conflict mitigation efforts; whilst some may look to research-based knowledge as the bringer of truth, its interpretation by different actors may exacerbate existing rifts between stakeholders, promoting polarisation of their views. 
Mitigation strategies should therefore be sensitive to this, and aim to improve the inclusiveness and transparency of the knowledge transfer process.

Keywords

Conservation conflicts; Conflict mitigation; Knowledge Use; Land Use; Environmental Management

\section{Introduction}

Conservation conflict currently poses one of the most significant challenges to wildlife conservation across the globe (Woodroffe et al., 2005; Redpath et al., 2013; 2015; Torres et al., 2018; Troumbis et al., 2018). Notoriously complex, such conflicts go beyond the superficial dispute over species impact and persist due to underlying social factors such as clashing values and social norms (Skogen, 2003; Miall, 2004; Madden and McQuinn, 2014). Furthermore, conflicts involve multiple actors at multiple levels; from stakeholders "on-the-ground" to non-governmental organisations (NGOs) and government bodies, as well as the wider public and the media (Jasanoff, 1998; Carvalho, 2007; Watts and Maddison, 2012; Veríssimo and Campbell, 2015; Lunstrum, 2017). Such situations are therefore difficult to assess and manage, and can be costly and detrimental to both conservation initiatives and human lives and livelihoods (Woodroffe et al., 2005; Redpath et al., 2013).

A high-profile conservation conflict in the UK exists around the conservation of raptor species and the management of upland moorland for the sport of shooting red grouse, Lagopus I. scoticus (Thirgood et al., 2000; Marshall et al., 2007). Historically many species of raptor were hunted to local extinction, following concerns of the economic losses incurred by the predation of game birds (Lovegrove, 2007). Following legal protection in 1954 and subsequent conservation efforts, some populations of raptor have recovered - yet evidence suggests raptors continue to be illegally killed on land managed for driven grouse shooting (Etheridge, 1997; Whitfield et al., 2003; Amar et al., 2012). However, this dispute is embedded within wider debates over land ownership and environmental governance in Scotland (Marshall et al., 2007; Dinnie et al., 2015; Hodgson et al., 2018). Over the last few decades the conflict has escalated - involving a range of stakeholders at multiple levels - and has become entrenched (Dinnie et al., 2015; Young et al., 2016a). Several issues, including the illegal killing of raptors, have received extensive coverage in the media, are the driving force behind public lobbying groups and petitions and, as such, are a subject of parliamentary debate (e.g. Cullen, 2017; Raptor Persecution UK, 2017). Some authors have suggested that deep-rooted social elements underlie this conflict, affecting the attitudes and relationships of the stakeholders involved, and so require further attention (Marshall et al., 2007; Thirgood and Redpath, 2008; Young et al., 2016b; Hodgson et al., 2018). 
On such social factor that may have influence is the use of knowledge (Butler et al., 2015; Young et al., 2016a). Research-based knowledge in particular - here understood as peer-reviewed papers, commissioned reports and scientific evidence or data (e.g. Thompson et al., 2001) - is a prominent feature in debates over environmental issues and conservation objectives (Weingart, 1999; Turnhout et al., 2008). Research is used frequently to address and define environmental problems, offer solutions, and inform management and/or policy decisions (Allen et al., 2001; Blaikei, 2001; Wesselink, 2009; Krange and Skogen, 2010). However, scholars have begun to highlight the importance of how research-based knowledge is interpreted, communicated and reconstructed (Verma et al., 2017; Crouzat et al., 2018; Tinch et al., 2018). Such knowledge is regularly referenced by stakeholders, who may not communicate research in its original form, but provide a certain interpretation of the findings (Carvalho, 2007; Buchanan et al., 2013; Skogen et al., 2017). Stakeholders involved in conflicts around the objectives of conservation and natural resource management often hold divergent and strongly-held values regarding these subjects and will whether purposefully or subconsciously - attempt to legitimise and reinforce them, with researchbased knowledge often used as a tool for doing so (Dinnie et al., 2015). For example, particular attention may be given to research that aligns with a certain value, and evidence that appears to challenge it selectively ignored (Bingham, 2003; Wesselink et al., 2013). Similarly, research-based knowledge may be used to de-legitimise the claims of opposing actors, or directly challenge 'dominant' discourses on wildlife management (Neves-Graça, 2004; Briggs, 2006; Waylen and Young, 2014; Skogen et al., 2017; Verma et al., 2017). It is not, therefore, the research based-knowledge itself that has a role to play in debates over wildlife management and environmental issues, but the way in which it is used and interpreted by conflicting actors.

Different modes of knowledge use and interpretation by various actors have been explored within the fields of land-use policy (e.g. Cowell and Lennon, 2014), marine resource use (Cvitanovic et al., 2015; 2015), ecosystem services (McKenzie et al., 2014) and climate change policy (Lemos and Morehouse, 2004). However, much of the literature focusses on knowledge use at the science-policy interface (i.e. how research is transferred from 'producer' (researchers) to 'user' (policy makers)) or the role of the media in communicating science to the public (e.g. Crouzat et al., 2018; Tinch et al., 2018). Less attention has been paid to the use of research-based knowledge by contending stakeholders in conservation conflict situations, and its contribution to the conflict. Verma et al. (2017) investigated the use of data specifically from technological devices by actors involved in a conflict in Cornwall, UK. However, the use of peer-reviewed papers and commissioned reports - as well as explicit technical data - in conservation conflicts has, to our knowledge, not yet been explored. We aim to address this knowledge gap by examining how research-based knowledge is used and interpreted by actors 
involved in the conflict over raptor conservation and grouse moor management in Scotland, and what implications this may hold for the persistence and mitigation of this conflict. Discourse analysis was used to investigate 1) the different ways in which actors are using research-based knowledge discursively; 2) how research is interpreted and 3) what this means for the relationships between these actors, and the conflict itself. Answering these questions is important to the development and implementation of future strategies that can improve inclusiveness, transparency, and trust between stakeholders, and thus lead to more effective conflict management (Næss, et al., 2013; Young et al., 2016b).

\section{Theoretical Frame}

Value Systems

This paper is centred around the concept that the ways in which different stakeholders communicate and reconstruct research is guided by strongly-held value systems. A value can be defined as an enduring belief that a particular "code of conduct" is superior to others, a social standard that guides and justifies actions or behaviour (Rokeach, 1968). A value system is a hierarchal arrangement of several values (Wiener, 1998). Some values in the system may be stronger than others and exert more influence, but ultimately the function of a value system is to allow the actor to make decisions about alternative modes of conduct, and resolve personal conflicts about them (Rokeach, 1968). Particularly in conservation conflicts, institutions are central actors (Jasanoff, 1998). It has been thought that the attitudes, decisions, and behaviour of an institution stems from a 'crystallisation' of one or several values, or a wider value system (Fischer and Van der Wal, 2006).

In regard to research-based knowledge, values and value systems may influence what is interpreted as relevant, how the research is framed, and who or what is deemed an authoritative source of information (Fazey et al., 2006; Carvalho, 2007; Raymond et al., 2010; Lemos et al., 2012; Cvitanovic et al., 2015; von Essen and Hansen, 2015). Research is therefore not communicated in its original form, but reconstructed based on such value systems (Carvalho, 2007). We argue that this influences how knowledge is used, and its role within the conflict (see figure 3.1). 


\section{Research based knowledge}

VALUE SYSTEM

\section{Conceptual use}

\section{Strategic use}

Figure 1: Visual representation of the theoretical frame used by this study, detailing the possible process of knowledge use by actors in the conservation conflict between raptor conservation and grouse moor management in Scotland. Process begins with the top box, labelled "research based knowledge". Arrows indicate the way in which knowledge is taken and used. Whilst it could be argued that the creation of research-based knowledge is also informed by values (e.g. Verma et al. 2017), these processes are not shown here as they were not the focus of this analysis. 
Knowledge Use Theories

The literature identifies three main typologies of knowledge use. Instrumental use can be defined as "the direct use of knowledge (seen as facts) to solve policy problems by filling data gaps or reducing uncertainty" (Waylen and Young, 2014). In this model of knowledge use, technical information is used directly to inform policy and management decisions (Davoudi, 2006). However, this is a relatively simplified view of knowledge use; policy problems are rarely as straightforward (Lemos et al., 2012). It has also been suggested that too heavy a focus on instrumental use will likely cause feelings of frustration and marginalisation amongst stakeholders, who may not rely exclusively on technical data to inform their decisions (Skogen et al., 2003; McKenzie et al., 2014).

Conceptual use is a broader perspective on knowledge use, which acknowledges that policy makers and resource managers are more influenced by tacit, informal and experiential knowledge, not simply explicit technical information (Newman, 2005; Fazey et al., 2006; Roux et al., 2006; Wesselink et al., 2013; Cvitanovic et al., 2015; Ntshotsho et al., 2015). This typology refers to the use of knowledge predominantly to further understanding of a topic, broaden a concept and shape new beliefs and values - raising awareness, educating, and thus altering how people perceive an issue (Garrett and Islam, 1988; Dunlop, 2014). It is through this persuasion and change in perception that the conceptual use of knowledge may exert influence, and policy change occurs as a by-product (Weiss, 1979; Lemos and Morehouse, 2005; McKenzie et al., 2014). This separates conceptual use from strategic use although lines between the two types can blur (McKenzie et al., 2014). Strategic use denotes the tactical use of knowledge with the specific intention to drive for a specific action or agenda, typically to be translated into policy (Boswell, 2008). In the context of environmental issues, this could involve the leveraging of ecological knowledge to mandate funding or direct policy (Waylen and Young, 2014; Turnpenny et al., 2014). For example, academics working within the National Ecosystem Assessment (NEA) strategically used research to direct the allocation of funding in their favour by highlighting specific knowledge gaps (Waylen and Young, 2014). With respect to the purpose of this paper, we deem conceptual and strategic use as the most relevant modes of knowledge use employed by stakeholders in a conservation conflict situation. As instrumental refers to the direct use of research to inform policy, it is unlikely evidence of this would be demonstrated within our research, as we focus on news articles and not policy documents. 


\section{Methodology}

Data collection

This paper uses discourse analysis as a way of assessing knowledge use in conflict. Typically, conservation conflicts are created and sustained through discourses, which, in a very basic sense, are forms of social interaction (Idrissou et al., 2011; Hodgson et al., 2018). The way in which we describe the world is not a straightforward representation of reality, but an interpretation which is shaped by individual perceptions and values, as well as through communication with others (Hajer, 1995; Buijs et al., 2011; Schwedes et al., 2013). Discourses may therefore actively influence conflict, as discourses cultivated by the preferred interpretations and definitions of certain actors clash (Fischer, 1998; Hajer et al., 2006; Idrissou et al., 2011). Publicly available, written expressions of discourses, such as website articles and social media, serve as platforms for conflict, where actors use discourse strategically to "gain dominance" over one another (Carragee and Roefs, 2004; Gamson, 2005; Buijs, 2009; Hodgson et al., 2018). Analysis of these discourses therefore provides an ideal lens with which to examine the subtler aspects of conservation conflict, such as the discursive function of research-based knowledge in arguments over wildlife management.

Data was obtained in the form of news articles from the individual websites of six organisations (see Hodgson et al., 2018 for detailed methods regarding selection of these organisations): the Royal Society for the Protection of Birds (RSPB), the Scottish Raptor Study Group (SRSG), Scottish Natural Heritage (SNH), the Game and Wildlife Conservation Trust (GWCT), Scottish Land and Estates (SLE) and the Scottish Gamekeepers Association (SGA). Whilst not mutually exclusive, the mission statements of these organisations suggest a cross section of interests (see appendix B for mission statements). Although it is not possible to ascertain definite value systems, it is apparent that these organisations represent separate interests that may contribute to their individual value systems.

All news articles dated between January 2008 - the earliest date at which all six websites, in their current format, were active - and January 2017 were collated for analysis. A further selective process was then carried out to eliminate any irrelevant articles. An initial search identified articles that focussed on raptors, raptor management, or grouse moor management only $(n=324)$. These articles were then taken forward for analysis. 
Data analysis

An initial content analysis was performed on all articles, whereby the overall focus of the article was derived from common themes within the text, and codes developed from these themes (Hsieh and Shannon, 2005). Coding refers to a process by which segments of the data are carefully read and defined, according to which concept it represents (Young et al., 2014). This allows patterns to emerge from the data and enables the researcher to explore the relationships between these concepts (Boyatzis, 1998). The initial thematic analysis revealed nine central themes (see appendix A). All articles coded as 'Research (Re)' (see appendix A for detailed definition) were then subjected to a further analysis to ascertain the mode of knowledge use for the research referenced within that article. Two codes were formulated a priori to analysis using theories and ideas from relevant literature - strategic and conceptual (Strauss and Corbin, 1998; table 3.1). Data was then coded accordingly by the primary author. The software programme nVivo (v.8) was used for the storage, management and coding of data.

In cases where the same report was referenced by two or more actors, a more detailed, line by line analysis was conducted to investigate how it was interpreted by each actor. The main findings reported, any conclusions drawn, and any opinions or perceptions of the piece of research by that actor were recorded, and compared to the original findings.

\begin{tabular}{|c|l|}
\hline Knowledge Use Code & \multicolumn{1}{|c|}{ Definition } \\
\hline Conceptual (Con) & $\begin{array}{l}\text { Knowledge is used to change perception and/or } \\
\text { increase understanding of a specific topic or } \\
\text { argument e.g. raptors are in decline due to } \\
\text { illegal killing, as shown by new evidence from } \\
\text { [name of report] }\end{array}$ \\
\hline Strategic (Stra) & $\begin{array}{l}\text { Knowledge is used to drive for a specific action, } \\
\text { for instance legislative outcomes such as a new } \\
\text { law to be passed, or an act to be banned } \\
\text { e.g. results demonstrate that illegal killing is } \\
\text { linked to grouse moors, thus we lobby that the } \\
\text { sport of driven grouse shooting should be } \\
\text { banned }\end{array}$ \\
\hline
\end{tabular}

Table 1: Finalised definitions of the two coding categories used for discourse analysis 


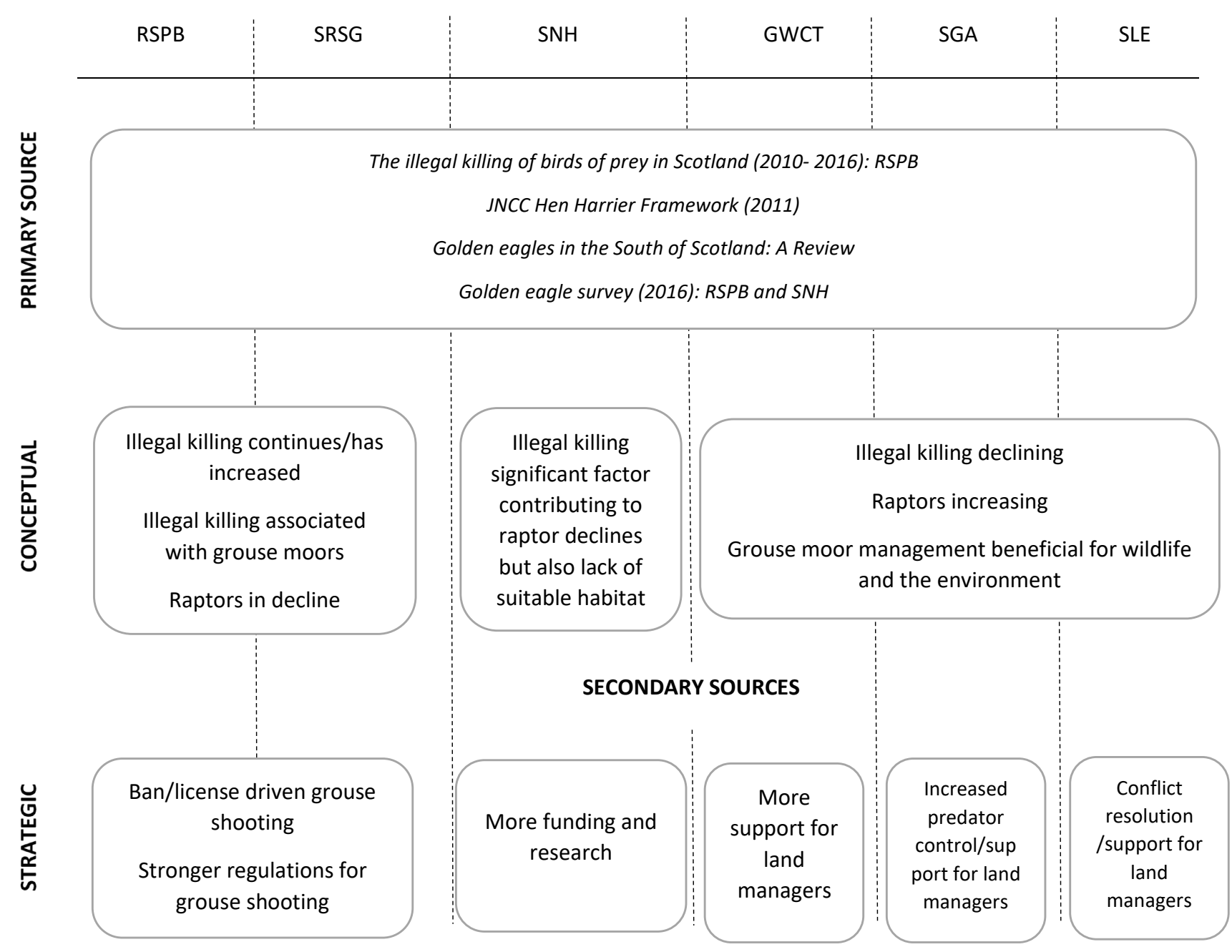

Figure 2: Summary of the use of research based knowledge by six organisations in the conflict around raptor conservation and grouse shooting in Scotland. Diagram illustrates the progression from the common primary sources used, to the conceptual and then strategic use of this knowledge. The main interpretations of the primary sources are detailed inside the grey boxes. 


\section{Results}

Conceptual and Strategic Knowledge Use

Conceptual was the predominant knowledge use type, with all six organisations utilising parts of research to raise awareness and increase understanding of a particular line of argumentation (figure 3.2). For example, RSPB and SRSG used data from the JNCC Hen Harrier Framework (Fielding et al., 2011), Golden Eagles in the South of Scotland: An Overview (Fielding and Hayworth, 2014) and The Illegal Killing of Birds of Prey in Scotland reports (RSPB, 2010; 2011; 2012; 2014) to illustrate their argument that raptors were being severely impacted and restricted by, namely, illegal killing and disturbance, and that these acts were rooted on land managed for grouse shooting. Evidence used emphasised declines in populations of raptors such as the hen harrier and red kite, and absences of other species, such as the golden eagle, from land managed for driven grouse shooting. Illegal killing was often stated as "the single biggest constraining factor" (RSPB, SRSG) of raptor populations across Scotland, and specific results used to denote that those employed by shooting estates were the culprits (" $85 \%$ of cases occurred at the hands of gamekeepers" - SRSG). Furthermore, other research papers (e.g. The Uplands: A Burning Issue) were used to introduce the concept that other aspects of grouse moor management - such as burning, predator control and medicated grit - had negative impacts on biodiversity and the health of the heather moorland ecosystem.

SNH also used the Hen Harrier Framework (Fielding et al., 2011) to highlight declines in hen harrier populations, and to link this to illegal killing. However, whilst illegal killing was labelled as a "significant" factor, SNH differed from RSPB and SRSG by referring to other "constraining" factors from the report, such as habitat degradation and predation, or even collisions with and disturbance caused by wind farms. Similarly, the absences of golden eagles from some parts of the country were highlighted, but instead used to illustrate that prime eagle habitat was threatened as opposed to focussing on the negative impacts of grouse moor management.

GWCT, SGA and SLE used knowledge conceptually in a different way - to change perception of the shooting industry and other "rural" land use practices, such as farming. A combination of GWCT commissioned research and Scottish government reports (PACEC, 2006; Scottish Government; 2010) were used to highlight possible positive aspects of these industries, supporting the view that they had both economic and ecological aspects. Results that appear to show high levels of bird diversity on grouse moors (e.g. Hoffman and Rohe, 2015) and agricultural land (e.g. GWCT; 2014) were reproduced in the discourse. Similarly, evidence supported the claim that game keeping practices specifically by controlling predators - benefitted wildlife, including raptors. These statements were 
backed up by data from projects such as the Langholm Moor Demonstration project and PAW Scotland's 'Heads Up For Harriers', which began in 2015. It was stated by GWCT that reports such as this should be used to "change common perception" that land management was damaging for wildlife and conservation. Furthermore, such results - showing evidence that game keeping and associated management practices were in fact beneficial for raptors, and that they were present on grouse moors - were emphasised alongside those that demonstrated a decline in illegal killing incidents, specifically poisoning. Data from the Science and Advice for Scottish Agriculture (SASA), PAW Scotland's Poisoning Hotspot Maps and even the RSPB Illegal Killing of Birds of Prey in Scotland reports were all quoted as evidence that supported the view of illegal killing declining.

The strategic use of knowledge was never observed on its own. Instead, the same piece of research that had been used conceptually was then taken forwards and used strategically, often within the same article (figure 3.2). For example, evidence used by RSPB and SRSG that validated raptor declines and a continuation of illegal killing was then used again to drive for stronger law enforcement and more funding to be allocated to authorities such as the National Wildlife Crime Unit (NWCU). Similarly, results that evidenced a link between illegal killing incidents and grouse moors were used to push for laws such as vicarious liability to be enforced, and then - once this had been introduced in 2014 - to drive for licensing of driven grouse shooting (whereby any persecutor on trial would cause the licence to shoot of his or her estate to be revoked). Furthermore, knowledge such as this was also used strategically to persuade the reader to sign a petition in support of this action.

Whilst SNH also highlighted the declines and absences of raptor populations, knowledge was never used strategically by this organisation to strive for increased law enforcement to place pressure on grouse moors. Instead, research was used to push for more research into the impacts of predation and wind farms as well as a funding boost for habitat restoration projects. Strategic use of knowledge by SGA was to drive for legalised predator control, beyond its current limits - in particular, licenses to cull common buzzards, Buteo buteo - to protect gamebirds and other ground nesting species, such as waders. Data suggesting the benefits of predator control and other aspects of land management by gamekeepers was used by both SGA and SLE to suggest increased amounts of land needed to be managed by and for grouse shooting interests, and more support for grouse moor management and the industry in general. Additionally, information that was first used conceptually to support the view of illegal killing declining was then used strategically to drive for the development of adaptive management solutions and the "resolution of conflicts" (SLE). 
Knowledge Interpretation

Organisations frequently quoted the same piece of research based knowledge when initially making a claim - the 'primary' source (see fig. 2). However, although the source was the same, how the findings were then interpreted differed between organisations. Following this, organisations would then refer to a subset of other information sources ('secondary' sources) that aligned with this specific interpretation. They also discussed secondary sources and the interpretations of other actors and used them to strengthen their argumentation. The following examples illustrate the process of knowledge use in more detail.

The Illegal Killing of Birds of Prey in Scotland (2012)

The Illegal Killing of Birds of Prey in Scotland - an annual report authored by RSPB - was referenced by five organisations, with the exception of GWCT. The 2012 report in particular was mentioned frequently, and interpreted in different ways by each organisation. RSPB stated a decline in poisoning incidents in comparison to previous years, but also an increase in other forms of illegal killing - such as shooting, trapping, and nest destruction. RSPB presented the report as evidence of the increased "persecution" of birds of prey, which was "exacting a heavy toll" on the country's populations. RSPB also emphasised a "strong association" between land managed for driven grouse shooting and illegal killing. Like RSPB, SRSG acknowledged a decrease in poisoning incidents, but emphasised that illegal killing - taking place on grouse moors - was still occurring at "wholly unacceptable levels". The report was described positively by RSPB, SRSG and SNH, being labelled as a "recording benchmark" (SRSG) and "unique record" (SNH).

In contrast, the report was described as "speculative" by SLE, based on the assumption that the report was a collation of largely "unconfirmed" cases of illegal killing. Both SGA and SLE interpreted the findings as showing a decline in illegal killing incidents - and implied that results which suggested the contrary were untrue and an emotive interpretation by the authors, RSPB: "[the findings in the report are] an opinion that RSPB are fully entitled to" (SGA). To support their interpretation, SGA and SLE referred to their secondary sources - Scottish government statistics and the PAW Scotland Hotspot Poisoning Map (2011). It was inferred that because the maps cited used only incidents confirmed as "deliberate abuse" by the SASA - as opposed to cases where a bird had been found but cause of death was unclear - they were more respectable ("we strongly encourage the reader to refer to the official government statistics" - SGA). 
RSPB, SRSG, SNH and SLE all discussed the 2011 Hen Harrier Conservation Framework from JNCC (Fielding et al., 2011). Again, organisations differed in the results they chose to report. RSPB reported that that although there was capacity in the uplands for 300 individuals, illegal persecution was the constraining factor that kept numbers below this; SRSG shared this interpretation, adding that very few harriers nested on driven grouse moors. Similar findings were quoted by SNH - that persecution was a "significant factor limiting the growth of hen harriers" and that this was a particular issue on grouse moors. However, SNH mentioned additional parts of the report, stating that it showed growth of some populations in Britain, and identified other "key areas of research needed", such as predation and suitable nesting habitat. In contrast, the only finding reported from SLE was that harriers were of 'favourable conservation status' in Scotland - no reference was made to illegal killing or declines.

Golden Eagles in the South of Scotland: An Overview

RSPB, SRSG, SNH, SLE and SGA all made reference to, Golden Eagles in the South of Scotland: An Overview (Fielding and Hayworth, 2014). They were said by RSPB to show an absence of golden eagles from the central highlands, where much land was managed for driven grouse shooting - thus, illegal killing on driven grouse moors was inferred. Numbers of occupied territories were said to be "looking positive" by SRSG, but breeding success in the West Highlands was reported as poor - on and around areas managed for grouse. Instead, SNH stated that with suitable conditions, Scotland could see many more breeding eagles in the future. There was no mention of vacant territories in the central highlands or areas where breeding had failed.

Similarly, SLE stated the report showed golden eagles could thrive under "suitable conditions". But whereas inferences were made by RSPB as to the association with grouse moors and eagle absences from the central highlands, SLE stated limiting factors as forestry, poor food supply, lack of potential nesting habitat and recreational disturbance. Furthermore, a "lack of prey availability" was cited as a result of the cessation of game keeping activities in these areas. Instead offielding and Hayworth (2014), ), SGA referenced their own Golden Eagle Survey - the main finding being 58 nesting golden eagles found on estates managed for grouse shooting. The results were said to have been "impossible without the use of local knowledge". Golden eagles were also said to be "sensitive to a lack of prey", afforestation, and windfarms - all factors said to be "cited by scientists". SGA claim they were advised not to produce a full publication on the premise of protecting the birds. However, RSPB discredited the survey and state that it is SRSG's 2015 national survey ("carried out by trained raptor monitors and ecologists, and using scientific methodology") that is the "test that counts". 


\section{Discussion}

This research suggests that the use of research-based knowledge by organisations involved in the conflict between raptor conservation and grouse moor management is not a straightforward process. Research-based knowledge served important functions - as a tool to change perceptions, justify certain views and support a specific line of argumentation; but also to drive for actions and policy changes that cause these views and goals to become reality. Knowledge is thus interpreted and used in a way that aligns with these functions. It is important to emphasise that this is not necessarily 'right' or 'wrong'; such actors have their own agendas and goals which influence how they interpret and portray a situation (section 2.4). However, how knowledge is used and construed may hold important implications for how the conflict itself plays out, especially with regard to the relationships between actors, and their willingness to collaborate and engage with conflict mitigation strategies.

Implications for relationships and conflict management

Work by Carvalho (2007) has shown that the interpretation of research based knowledge inherently stems from, and reinforces, divergent value systems. While an empirical demonstration of the link between values and knowledge use was not within the scope of our analysis, we argue that a similar process could be occurring in how actors involved in the conflict between raptor conservation and grouse moor management interpret and use research-based knowledge. Furthermore, if the interpretation and use of knowledge is indeed value-driven, it may have a role in shaping the conflict itself (Young et al., 2016a; Verma et al., 2017). Factors that contribute to value systems - such as political and social preferences, and judgements of others (Carvalho, 2007) - as well as trust and mutual understanding, have all been suggested to influence knowledge use within other environmental debates (Greenhalgh and Wieringa, 2011; Bracken and Oughten, 2013; Nutley et al.,2013). All of these factors have also been proposed to shape conservation conflicts (Madden and McQuinn, 2014; Redpath et al., 2015; Young et al., 2016b; Torres et al., 2018). It could therefore be assumed that there is interplay between knowledge use and conflict - one influences the other. Not only does the use of knowledge influence conflict, but conflict in turn may shape how new knowledge is created and then interpreted (Verma et al., 2017).

In this paper, interpretation of knowledge by organisations was related to their view of the 'status quo', and its role was therefore to legitimise or challenge it. For example, GWCT referenced The Big Farmland Bird Count (2016) to "change perceptions that land managed for grouse moors and farming 
is bad for wildlife". Similarly, SGA and SLE used evidence to defend the environmental and ecological benefits of game keeping practices - in particular, predator control. Dinnie et al. (2015) describe similar findings after investigating the attitude of landowners towards environmental governance in Scotland; stakeholders in the game and wildlife sector felt under threat from increasingly 'dominant' discourses that were perceived to challenge their way of life. Knowledge formed a way to push back against this governance, and to prove the validity of their own expertise. Research-based knowledge is often used in this manner by actors who feel another argument or interpretation has power within the debate, and as such is used as a way to challenge 'dominant' discourses over wildlife management (Neves--Graça, 2004; Holmes, 2007; Negev and Teschner, 2013; Skogen et al., 2017). Perhaps the most obvious evidence of this was the response of SGA to the results of Fielding and Hayworth (2014) using their own Golden Eagle Survey. The survey claims to counter the results of these reports which state that nesting individuals are absent from large areas of Scotland, notably that managed for driven grouse shooting (Fielding and Hayworth, 2014) - by showing "58 nesting pairs of eagles in areas managed for grouse shooting" (SGA). It was stated by SGA that this survey would have been "impossible without the incorporation of local knowledge", which the SNH report was said to have lacked.

When actors wanted to challenge the status quo, they often demonstrated conceptual use of knowledge. This is also reflective of the literature; conceptual use of knowledge has been shown to be employed more by actors when they were seeking to engage recipients with environmental issues, and 'transform' their ideas and perceptions relating to a particular topic (Haines-Young and Potschin., 2014; Mckenzie et al., 2014). Conceptual use has even been referred to as 'enlightenment', because of its purpose to increase understanding and in some cases, persuade others into that way of thinking (Owens, 2005; Dunlop, 2014). However, this also allows divergent interpretations to spread and grow, especially in light of the recent advancement of communicative channels such as social media (Andersson and Ohman, 2016; Büscher, 2016; Lunstrum, 2017). Certainly, social media is a part of the current conflict over raptors, with several blogs detailing the interpretations of scientific research as put forwards by the focal organisations within this study e.g. "Shameful catalogue of raptor persecution shown in RSPB's BirdCrime report" (Raptor Persecution Scotland; 2015), "New gamebird figures challenge RSPB claims" (Layton, 2015).

A further function of research-based knowledge suggested by this analysis was to discredit and disparage the claims of other actors, identifying their statements as false or untrue and in some cases, accusing the other group of attacking their core values. This was evidenced in views of SGA and SLE, denoting that RSPB's claims were "unofficial and speculative" (SGA) and employed as a tool to turn others against them, and in the strategic use of research by RSPB and SRSG, using the Illegal Killing of 
Birds of Prey in Scotland (2012), which was used to drive for the increased regulation of the shooting industry and dismiss the SGA's claims that illegal killing was decreasing. Knowledge has been said to create and sustain identities within debates over land management and wildlife conservation, allowing actors to defend their own rights and outline their opposition by challenging the credibility of their claims and knowledge sources (Dunk, 2002; Nursey-Bray et al., 2010; Dinnie et al., 2015; Hulme, 2015). This too aligns with the concept of value systems. Values demonstrate a distinct preference for a specified code of conduct, which influences what is accepted as the norm, and what actions and opinions are justified (Rokeach, 1968). They provide the standard by which we validate the behaviour of others, morally judge, and decide which aspects of society we would like to challenge. By challenging the status quo, the actors examined in this study may be attempting to assert their own value systems using research-based knowledge, and defy those of others. This then means that divergent value systems are sustained, promoting differences as opposed to a common, shared goal which only serves to further existing disputes (Verma et al., 2017).

Therefore, we argue that this process of 'who knows best' promotes incongruity between stakeholders and allows disagreements to grow and intensify, heightening already realised tensions (Sarewitz et al., 2004; 2011; Wesselink et al., 2013; Skogen et al., 2017; Verma et al., 2017). A mutual distrust between stakeholder groups is therefore created and sustained, undermining effective exchange of information and dialogue (Kinzig, 2001; Briggs, 2006; Roux et al., 2006; Redpath et al., 2015; Young et al., 2016b). On the other hand, this can also empower groups who feel they have become marginalised, by allowing them to have a voice and influence (Berkes, 2009; Wesselink et al., 2014). In some cases, the incorporation of different value systems and knowledge has caused debates over environmental management to be rectified (Nel et al., 2016). Regardless, it is apparent that the use of research-based knowledge has influence over how conservation conflicts are shaped, and mitigation strategies should be sensitive to this.

\section{Self-Censorship}

When knowledge is seen to be controversial - e.g. a report that contradicts policy, or challenges popular opinion - actors may exercise "self-censorship", whereby they avoid discussing it completely (Tennøy et al., 2016). This, in a way, is also a form of knowledge use; the selective reporting of some parts of research, and neglect of others (Provençal, 2011; Fazey et al., 2012; Tennøy et al., 2012). GWCT were the only organisation that did not refer to an Illegal Killing of Birds of Prey in Scotland report, or indeed many of the others that were focussed on raptors as discussed by other organisations, instead relying largely on their own research which looked into best practice for grouse moors, and the ecological and economic benefits of land management (e.g. Singing Fields (GWCT, 
2007). Similarly, SNH referenced only results that highlighted the ecological reasons behind raptor declines, steering clear of the topic of illegal persecution, and promoted the economic benefits of species such as the white-tailed eagle.

In itself, self-censorship by organisations is not antagonistic; it does not directly dismiss the views of others, or challenge them. In fact, it may not be intentional or deliberate. However, we argue it could add to the tensions that already exist in conservation conflicts, as it may contribute to the perception that important pieces of expert knowledge are becoming omitted on the basis that they are deemed politically unacceptable - causing stakeholders who believe the issue to be of great importance to become frustrated (Turnpenny et al., 2014; Tennøy et al., 2016). This could further serve to alienate such groups, and encourage disagreements over what constitutes 'legitimate' evidence (Cook et al., 2013; Young et al., 2016b). Therefore, self-censorship and the 'filtering' of research-based knowledge could prove problematic for conflict mitigation.

The wider implications of knowledge use and interpretation, and ways forward

Research-based knowledge, rooted in science, is often accorded a certain privilege and sense of authority that other modes of knowledge are not (Allen et al., 2001; Waylen and Young, 2014). Research is often seen as the 'bringer of truth' - environmental issues are habitually framed scientifically, and as such scientific expertise is seen as the authority on such issues (Yearley, 1995; Turnhout et al., 2012; Wesselink et al., 2013). Therefore, research-based evidence is perceived to lend credibility and legitimacy to claim-making (Buchanan, 2013). However, as demonstrated by this study, research-based knowledge - as any other type of knowledge - is socially constructed, interpreted and subsequently communicated in a way that corresponds with different value systems. We have explored the ways in which this may affect relationships between contending actors in a conflict situation, but it may also have important wider implications that should be considered.

One such consideration should be how these interpretations may diffuse into environmental policy and decision-making processes. It has been suggested that peer-reviewed papers - in their explicit, original form - are not popular sources of information with planners and practitioners (Owens, 2005; Krizek et al., 2009). Scientists often see their research as something that provides potential answers and guidance, whereas planners and practitioners want directly applicable solutions (Callon, 1999; Jasanoff, 2003)). Whilst science is respected by the latter, it is not necessarily used in the way that the researchers first intended (Dessai et al., 2009; Lemos et al., 2012). Rather, whilst policy-makers and resource managers have an interest in science, their decisions are still influenced by tacit, informal and experiential knowledge, as well as the interpretations put forwards by other, powerful interests 
(Fazey et al., 2006; Roux et al., 2006; Cook et al., 2010; Wesselink et al., 2013; Cvitanovic et al., 2015; Ntshotsho et al., 2015). Such 'powerful' interests can include various different groups. NGOs - such as RSPB - are increasingly being recognised as important contributors to policy and decision making, with an influential role in campaigning and public engagement (Jasanoff et al., 1998; Eden et al., 2006). In Scotland particularly, wealthy landowners with well-established political links and business influence can also dominate policy decisions (Dinnie et al., 2015). Research-based knowledge has an important role in assisting these groups to sway policy, as demonstrated by the evidence of strategic knowledge use in our research. The strategic use of knowledge by business firms is important in gaining a 'competitive advantage' over the opposition, and knowledge is even referred to as a 'strategic asset' (Bou-Llusar and Sigarra-Cipres, 2006). In the context of conservation conflict, knowledge may provide a competitive advantage in the sense of engineering policy in favour of a certain goal (Bingham, 2003; Wesselink et al., 2013).

If policy is seen to reflect one interpretation over another, it could have implications for conflict situations. Firstly, it may promote confusion over what is 'truth', reducing the validity of the original findings, and causing innovative solutions to be overlooked ( Næsset al., 2013; Tennøy et al., 2016). Secondly, if policy decisions are based on the dominant view and not the full picture, this undoubtedly will privilege certain actors, whilst excluding others and/or their needs (Turnhout et al., 2012; Young et al., 2014). This may cause frustration within certain stakeholder groups, who perceive their own issues and concerns as being neglected (Turnpenny et al., 2014). Most recently within this specific case of conflict, a Scottish Government report looking at the movements of satellite tagged golden eagles - commissioned in 2016 after individuals were reported 'missing' - was used as leverage by organisations such as RSPB to fight for action on behalf of the government (e.g. Cullen, 2017). In November of the same year, the Scottish Government announced a proposal for a 'Grouse Moor Management Review Group', aimed at reviewing practices led on grouse moors and, potentially, advise on a licencing scheme for the industry (Raptor Persecution Scotland, 2017). This may exacerbate perceived feelings among shooting interest groups of exclusion and of their concerns surrounding predation by raptors being 'ignored' by conservationists, as identified by previous study (see section 2.4). Further research is required to look into the actual influence of the strategic use of knowledge on policy decisions within the Scottish government, regarding raptors and grouse moor management, but the potential to aggravate conservation conflict situations is apparent.

This is not to say that research does not have an important role in conflicts. Research-based knowledge is a tool with which to engage and enlighten stakeholders and local communities, and inform management decisions (Weiss, 1979; Allen et al., 2001; Krange and Skogen, 2010; Buchanan, 2013). Processes that aim to improve how this knowledge is communicated by and between actors, 
such as knowledge co-production, have been suggested and even recommended as solutions to environmental debates. Knowledge co-production involves collaboration between a diverse set of stakeholders, with a range of knowledge types, to build a shared understanding of the problem and work iteratively towards a common goal (Armitage et al., 2011; Nel et al., 2016). It has been demonstrated to improve the inclusiveness of research by placing stakeholders - and their preferred source of knowledge - on equal footing, allowing commonalities to be revealed within their interests and goals, as opposed to their differences (Jasanoff et al., 2004; Armitage et al., 2011; Young et al., 2014; Nel et al., 2016). Furthermore, evidence suggests that the more stakeholders are involved in the production of knowledge, the more likely they are to accept it as legitimate (Cash et al., 2003; Tengö et al., 2014; Young et al., 2016b). Co-production processes in the Dutch Wadden Sea were so successful at helping the local communities and authorities to work together on creating 'socioecologically appropriate fishing ports', and promoting 'clean' ports that employed conservation measures, that such processes were recommended as mandatory for future coastal management, on the basis of their ability to stimulate dialogue (Puente-Rodriguez et al., 2016).

It should be noted that attempts have been made to foster knowledge co-production to resolve issues around raptor conservation and grouse shooting. From 1992 to 1997, the Joint Raptor Study (JRS) was undertaken - a five year study which aimed to assess the impact of raptor predation on numbers of grouse across six different grouse moors and eight study sites (Redpath and Thirgood, 1997; Thirgood and Redpath, 1997; Redpath and Thirgood, 2009). The results indicated that whilst the impact of hen harriers varied spatially and temporally, at high densities their predation could limit grouse populations and reduce shooting bags (Thirgood et al., 2000). In 1997, the Moorland Working Group (MWG) was established to address such conflicts, and comprised of RSPB, the Game Conservancy Trust (now GWCT), SNH, the Scottish Landowners' Federation and Buccleuch estates (Galbraith et al., 2003). This group worked alongside the Raptor Working Group, and produced a series of nontechnical publications regarding best practice management of moorland aimed at grouse moor managers and owners to help build understanding of various habitat management options (Moorland Working Group, 2002), and, in 1998, developed a major field experiment testing the efficacy of supplementary feeding as a means of reducing harrier predation on red grouse (Redpath et al., 2001). Its successor, the Moorland Forum, also commissioned several projects investigating mitigation techniques (e.g. Naylor et al., 2005). In 2008, the Langholm Moor Demonstration Project began as a long-term project with the aim of attaining a viable driven grouse moor alongside a sustainable population of hen harriers, and involved collaboration among a range of stakeholders to experiment with habitat management, predator control, and diversionary feeding (Thirgood and Redpath, 2008; Langholm Moor Demonstration Project, 2014). Langholm remained as a study site until January 2018, 
whereupon it was agreed by partners that the project was complete (Langholm Moor Demonstration Project, 2018).

However, despite several publications and a decade of joint working, there is still disagreement over management options and many other issues related to raptors and grouse shooting (Redpath and Thirgood, 2009; Hodgson et al., 2018). For example, some stakeholders are still polarised over why the Langholm Moor Demonstration Project failed to meet the objective of achieving a sustainable grouse moor, almost four years on from the final report (Langholm Moor Demonstration Project, 2014; Hodgson et al., 2018). There has been little scholarly work to determine why such efforts at collaboration and knowledge co-production have been ineffective at resolving the conflict. Redpath and Thirgood (2008), suggest that a combination of the entrenched positions of stakeholders, a tendency to accept the situation as the 'status quo', limited shared understanding and a lack of money for long-term mitigative processes all contribute to the perseverance of this conflict. More recent examples (e.g. Ainsworth et al., 2016) and the findings of this chapter, and those that follow it, imply that these factors may indeed be the integral barriers limiting the effectiveness of knowledge co-production processes.

Whilst knowledge co-production could be a valuable aspect of future, long-term mitigation strategies aimed at resolving raptor conflict in Scotland, its success at this present moment would potentially be limited. As we have seen here, actors are - whether intentionally or unintentionally - interpreting and using research-based knowledge based on their own value systems, which are often different, and clash as a result. We suggest therefore that in the short-term, conflict managers should aim to address the issues that cause these divergent interpretations and work to improve relationships, leading the identification of a shared goal. What may be required to do so is a form of "hybrid" institution - who are not definitively positioned within the conflict, but concentrated on the common concerns and queries of stakeholders (Lindsey et al., 2016). Such bodies may help to bring together a shared vision and action plan, drawing expertise from all sectors. These have, and do exist to some extent in Scotland; associations such as Cairngorms Connect and the Moorland Forum, alongside projects such as 'Understanding Predation' have been created in recent years to establish more collaborative land management processes (e.g. Ainsworth et al., 2016). However, the wider opinion of such collaborative schemes is that presently, they remain largely ineffective due to a number of factors - including a lack of resources and failure to identify a common goal (pers. comm., 2017). We hypothesise that the effectiveness of these collaborative processes is hindered by the divergent value systems of the actors involved; although the intention to take part is apparent, strongly-held values affect the willingness of participants to let go of their own agendas. Similarly, such processes have either focussed on a specific management problem (e.g. predation) or improving land management in 
general - few have worked to resolve fractured relationships between the stakeholders involved. Therefore, we conclude that if hybrid institutions and knowledge co-production processes are to be successful, they must first acknowledge different value systems and encourage dialogue that addresses them. This may help to rectify damaged relationships, reducing polarisation and encouraging knowledge sharing - and only at this point, can a truly common goal be established.

\section{Conclusion}

Our research suggests that the use and interpretation of research-based knowledge reflects divergent value systems, and such knowledge use can therefore play an important role in conservation conflict, potentially reinforcing and exacerbating already realised tensions between stakeholders. Through investigating knowledge use by actors in the conflict between raptor conservation and grouse moor management in Scotland, we have found evidence of both the conceptual and strategic use of knowledge. Furthermore, these findings suggest that these uses stem from the specific interpretations of research that, in turn, may come from the different value systems of the actors that communicate them. Research was used selectively as a tool to debate, debunk one another's claims, exercise self-censorship, and to drive for specific policy action. This could serve to aggravate already fragmented relationships between these actors, decreasing the likelihood of collaboration and identification of a shared solution.

We conclude that for mitigation strategies to be successful, they must first address the root issues that cause divergent interpretations, before encouraging a common goal to be established. Only then can processes that aim to improve the inclusiveness of research - such as knowledge co-production and collaborative processes focussed on working towards a shared goal, begin to have impact.

\section{References}

Allen, T.F.H., Tainter, J.A., Pires, J.C. and Hoekstra, T.W. (2001) Dragnet Ecology_ “Just the Facts, Ma'am": The Privilege of Science in a Postmodern World: Science of intrinsic quality needs narratives with explicit values - not just facts - particularly as it faces multiple-level complexity in advising on environmental policy, such as planning for energy futures. BioScience, 51(6), pp.475-485.

Ainsworth, G., Calladine, J., Martay, B., Park, K., Redpath, S., Wernham, C., Wilson, M., Young, J., (2016) Understanding Predation. A review bringing together natural science and local knowledge of recent wild bird population changes and their drivers in Scotland. Moorland Forum. 
Amar, A., Davison, M., Downing, S., Grimshaw, T., Pickford, T. and Raw, D. (2012) Linking nest histories, remotely sensed land use data and wildlife crime records to explore the impact of grouse moor management on peregrine falcon populations. Biological conservation, 145(1), pp.86-94.

Andersson, P. and Öhman, J. (2016). Logics of business education for sustainability. Environmental Education Research, 22(4), pp.463-479.

Armitage, D., Berkes, F., Dale, A., Kocho-Schellenberg, E. and Patton, E. (2011). Co-management and the co-production of knowledge: learning to adapt in Canada's Arctic. Global Environmental Change, 21(3), pp.995-1004.

Berkes, F., (2009). Evolution of co-management: role of knowledge generation, bridging organizations and social learning. Journal of environmental management, 90(5), pp.1692-1702.

Bingham, N., (2003). Introduction. In: Bingham, N., Blowers, A.,Belshaw, C. (Eds.), Contested Environments. Wiley in Association with the Open University, Chichester

Boswell, C. (2008). The political functions of expert knowledge: knowledge and legitimation in European Union immigration policy. Journal of European Public Policy, 15(4), pp.471-488.

Bou-Llusar, C.J. and Segarra-Ciprés, M., (2006). Strategic knowledge transfer and its implications for competitive advantage: an integrative conceptual framework. Journal of knowledge management, 10(4), pp.100-112.

Boyatzis, R.E. (1998) Transforming qualitative information: thematic analysis and code development. Sage, London.

Bracken, L. and Oughton, L. (2013) Making sense of policy: the creative uses of evidence in managing freshwater environments. Environmental Science and Policy, 30 (2013), pp. 10-18

Briggs, S.V. (2006) "Integrating policy and science in natural resources: Why so difficult?" Ecological Management \& Restoration, 7(1) 37-39

Buchanan, K.S. (2013) Contested discourses, knowledge, and socio-environmental conflict in Ecuador. Environmental science \& policy, 30, pp.19-25.

Buijs, A.E. (2009) Lay people's images of nature: frameworks of values, beliefs and value orientations, Society and Natural Resources, 22, pp. 417-432 
Buijs, A.E., Arts, B.J., Elands, B.H. and Lengkeek, J. (2011) Beyond environmental frames: the social representation and cultural resonance of nature in conflicts over a Dutch woodland. Geoforum, 42(3), pp.329-341.

Buijs, A., Mattijssen, T. and Arts, B. (2014) "The man, the administration and the counter-discourse": An analysis of the sudden turn in Dutch nature conservation policy. Land Use Policy, 38, pp.676-684.

Büscher, B. (2016). Nature 2.0: Exploring and theorizing the links between new media and nature conservation. New media \& society, 18(5), pp.726-743.

Butler, J.R.A., Young, J.C., McMyn, I.A.G., Leyshon, B., Graham, I.M., Walker, I., Baxter, J.M., Dodd, J. and Warburton, C. (2015) Evaluating adaptive co-management as conservation conflict resolution: learning from seals and salmon. Journal of environmental management, 160, pp.212-225.

Carragee, K.M. and Roefs, W. (2004) The neglect of power in recent framing research. Journal of communication, 54(2), pp.214-233.

Callon, M. (1999) The role of lay people in the production and dissemination of scientific knowledge. Science, Technology and Society, 4(1), pp.81-94.

Carvalho, A. (2007) Ideological cultures and media discourses on scientific knowledge: re-reading news on climate change. Public Understanding of Science, 16, pp. 223-243

Cash, D.W., Clark, W.C., Alcock, F., Dickson, N.M., Eckley, N., Guston, D.H., Jäger, J. and Mitchell, R.B., (2003) Knowledge systems for sustainable development. Proceedings of the national academy of sciences, 100(14), pp.8086-8091.

Crouzat, E., Arpin, I., Brunet, L., Colloff, M.J., Turkelboom, F. and Lavorel, S. (2018) Researchers must be aware of their roles at the interface of ecosystem services science and policy. Ambio, 47(1), pp.97105

Cook, C.N., Mascia, M.B., Schwartz, M.W., Possingham, H.P. and Fuller, R.A. (2013). Achieving conservation science that bridges the knowledge-action boundary. Conservation Biology, 27(4), pp.669-678.

Cowell, R. and Lennon, M., (2014) The utilisation of environmental knowledge in land-use planning: drawing lessons for an ecosystem services approach. Environment and Planning C: Government and Policy, 32(2), pp.263-282 
Cullen, L. (2017) RSPB Scotland welcomes wildlife crime report. $8^{\text {th }}$ December 2017. Available at: https://www.rspb.org.uk/about-the-rspb/about-us/media-centre/press-releases/rspb-scotlandwelcomes-wildlife-crime-report/

Cvitanovic, C., Hobday, A.J., van Kerkhoff, L., Wilson, S.K., Dobbs, K. and Marshall, N.A. (2015). Improving knowledge exchange among scientists and decision-makers to facilitate the adaptive governance of marine resources: a review of knowledge and research needs. Ocean \& Coastal Management, 112, pp.25-35.

Davoudi, S. (2006) Evidence-based planning: rhetoric and reality. disP-The Planning Review, 42(165), pp.14-24.

Dessai, S., Hulme, M., Lempert, R. and Pielke, R. (2009) Do we need better predictions to adapt to a changing climate?. Eos, Transactions American Geophysical Union, 90(13), pp.111-112.

Dinnie, E., Fischer, A. and Huband, S. (2015). Discursive claims to knowledge: the challenge of delivering public policy objectives through new environmental governance arrangements. Journal of Rural Studies, 37, pp.1-9.

Dunk, T. (2002) Hunting and the politics of identity in Ontario. Capitalism Nature Socialism, 13, pp. 3666

Dunlop, C.A. (2014) "The possible experts: how epistemic communities negotiate barriers to knowledge use in ecosystems services policy. Environment and Planning C: Government and Policy, 32(2), pp.208-228.

Eden, S., Donaldson, A., Walker, G. (2006) Green Groups and Grey Areas: Scientific Boundary-Work, Nongovernmental Organisations, and Environmental Knowledge. Environment and Planning A, 38 (6) pp. 1061-1076

Etheridge, B., Summers, R.W., Green, R.E. (1997) The effects of illegal killing and destruction of nests by humans on the population dynamics of the hen harrier Circus cyaneus in Scotland. Journal of Applied Ecology, 34, pp. 1081-1105

Fazey, I., Fazey, J.A., Salisbury, J.G., Lindenmayer, D.B. and Dovers, S. (2006). The nature and role of experiential knowledge for environmental conservation. Environmental conservation, 33(1), pp.1-10.

Fielding, A., Haworth, P., Whitfield, P., McLeod, D. \& Riley, H. (2011) A Conservation Framework for Hen Harriers in the United Kingdom. JNCC Report 441. Joint Nature Conservation Committee, Peterborough. 
Fielding, A.H. and Haworth, P.F. (2014) Golden eagles in the south of Scotland: an overview. Scottish Natural Heritage Commissioned Report No. 626.

Fischer, F. (1998) Beyond empiricism: policy inquiry in post positivist perspective. Policy studies journal, 26(1), pp.129-146.

Fischer, A. and Van Der Wal, R. (2007) Invasive plant suppresses charismatic seabird-the construction of attitudes towards biodiversity management options. Biological Conservation, 135(2), pp.256-267.

Galbraith, C.A., Stroud, D.A., Thompson, D.B.A. (2003) Towardsresolving raptor-human conflicts. In: Thompson, D.B.A., Redpath, S., Fielding, A.H., Marquiss, M., Galbraith, C.A. (Eds.), Birds of Prey in a Changing Environment. The Stationery Office: Edinburgh, UK. pp. 527-535

Garrett, J.L. and Islam, Y. (eds) 1998. Policy Research and the Policy Process: Do the twain ever meet? In: Gatekeeper Series-Sustainable Agriculture Programme, International Institute for Environment and Development (United Kingdom).

Gamson, W. (2005). The Public Opinion Quarterly, 69(2), 324-326

Greenhalgh, T. and Wieringa, S. (2011). Is it time to drop the 'knowledge translation' metaphor? A critical literature review. Journal of the Royal Society of Medicine, 104(12), pp.501-509.

GWCT (2007) Singing fields: why gamekeeping helps birds in the countryside. [pdf] available at: https://www.gwct.org.uk/media/249264/singing fields report.pdf. Accessed: $12^{\text {th }}$ February 2016

GWCT (2014) Big Farmland Bird Count Results. [pdf] Available at:

https://www.gwct.org.uk/media/388634/Big-Farmland-Bird-Fact-Sheet.pdf. Accessed: $15^{\text {th }}$ March 2015

Haines-Young, R. and Potschin, M. (2014). The ecosystem approach as a framework for understanding knowledge utilisation. Environment and Planning C: Government and Policy, 32(2), pp.301-319.

Hajer, M. and Versteeg, W. (2005) A decade of discourse analysis of environmental politics: achievements, challenges, perspectives. Journal of environmental policy \& planning, 7(3), pp.175-184. Hajer, M.A. (ed) (1995) The politics of environmental discourse: ecological modernization and the policy process (p. 40). Oxford: Clarendon Press.

Hajer, M.A., van den Brink, M. and Metze, T. (2006) Doing discourse analysis: coalitions, practices, meaning. Netherlands geographical studies (ISSN 0169-4839), (344). 
Hulme, D., Savoia, A. and Sen, K. (2015) Governance as a Global Development Goal? Setting, Measuring and Monitoring the Post-2015 Development Agenda. Global Policy, 6(2), pp.85-96.

Hodgson, I.D., Redpath, S.M., Fischer, A. and Young, J., 2018. Fighting talk: Organisational discourses of the conflict over raptors and grouse moor management in Scotland. Land Use Policy, 77, pp.332343.

Hoffmann, D. \& Rohe, H. (2015): Excursion to Glenogil estate - Scotland. 26. IV. - 30. IV.

Hsieh, H.F. and Shannon, S.E. (2005) Three approaches to qualitative content analysis. Qualitative health research, 15(9), pp.1277-1288.

Idrissou, L., Aarts, N., van Paassen, A. and Leeuwis, C. (2011) The discursive construction of conflict in participatory forest management: the case of the Agoua forest restoration in Benin. Conservation and society, 9(2), p.119.

Jasanoff S. (1998) NGOs and the Environment: from Knowledge to Action. In: Weiss T.G. (eds) Beyond UN Subcontracting. International Political Economy Series. Palgrave Macmillan, London

Jasanoff, S. (2003). Technologies of humility: citizen participation in governing science. Minerva, 41(3), pp.223-244.

Layton, M. (2015) New gamebird figures challenge RSPB claims. 9 ${ }^{\text {th }}$ October 2015. In: Shooting UK News. Available at: https://www.shootinguk.co.uk/shooting/game-shooting/pheasantshooting/new-gamebird-figures-challenge-rspb-claims-47753. Accessed: $12^{\text {th }}$ January 2017

Langholm Moor Demonstration Project (2014) Seven year review - December 2014 [pdf] available at: http://www.langholmproject.com/PDF\%20downloads/7yr\%20review.pdf Accessed: 23rd July 2018

Langholm Moor Demonstration Project (2018) Available at:

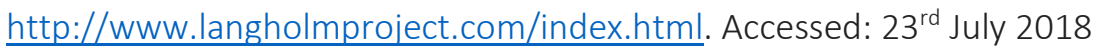

Lemos, M.C., Kirchhoff, C.J. and Ramprasad, V. (2012). Narrowing the climate information usability gap. Nature Climate Change, 2(11), pp.789-794.

Lemos, M.C. and Morehouse, B.J. (2004), "The co-production of science and policy in integrated climate assessments". Global Environmental Change, 15(1), pp.57-68 
Lindsey, P.A., Balme, G.A., Funston, P.J., Henschel, P.H. and Hunter, L.T. (2016) Life after Cecil: channelling global outrage into funding for conservation in Africa. Conservation Letters, 9(4), pp.296301.

Lovegrove, R., (2007) Silent fields: the long decline of a nation's wildlife. Oxford University Press, UK

Lunstrum, E., (2017) Feed them to the lions: Conservation violence goes online. Geoforum, 79, pp.134-143.

Kinzig, A.P., Pacala, S.W. and Tilman, D. eds. (2001) The functional consequences of biodiversity: empirical progress and theoretical extensions (Vol. 33). Princeton University Press.

Krange, O. and Skogen, K. (2010). The Hammertown mechanism. Cultural resistance and political marginalization. Transitions in Marginal Zones in the Age of Globalization: Case Studies from the North and South, 223, p.248.

Krizek, K., Forysth, A. and Slotterback, C.S., 2009. Is there a role for evidence-based practice in urban planning and policy?. Planning Theory \& Practice, 10(4), pp.459-478.

Madden, F. and McQuinn, B., (2014) Conservation's blind spot: The case for conflict transformation in wildlife conservation. Biological Conservation, 178, pp.97-106.

Marshall, K., White, R. and Fischer, A. (2007) Conflicts between humans over wildlife management: on the diversity of stakeholder attitudes and implications for conflict management. Biodiversity and Conservation, 16(11), pp.3129-3146.

McKenzie, E., Posner, S., Tillmann, P., Bernhardt, J.R., Howard, K. and Rosenthal, A., (2014).

Understanding the use of ecosystem service knowledge in decision making: lessons from international experiences of spatial planning. Environment and Planning C: Government and Policy, 32(2), pp.320340.

Miall, H. (2004) Conflict transformation: A multi-dimensional task. In: Austin, A., Fischer, M., Ropers, N. (eds.) Transforming Ethnopolitical Conflict (pp. 67-89). VS Verlag für Sozialwissenschaften.

Næss, P., Hansson, L., Richardson, T., Tennøy, A. (2013) Knowledge-based land use and transport planning? Consistency and gap between "state-of-the-art" knowledge and knowledge claims in planning documents in three Scandinavian city regions. Planning Theory \& Practice, 14 (4), pp. 470491 
Naylor, A., White, R., Mougeot, F. (2005) Assessing the Feasibility and Acceptability of Rear and Release, Trap and Transfer and the Use of Dovecotes as Management Options for Red Grouse. Report to Scotland's Moorland Forum, Edinburgh, UK.

Negev, N. and Teschner, M. (2013) Rethinking the relationship between technical and local knowledge: towards multiple types of knowledge. Environmental Science and Policy, 30, pp. 50-59 Nel, J.L., Roux, D.J., Driver, A., Hill, L., Maherry, A.C., Snaddon, K., Petersen, C.R., Smith-Adao, L.B., Deventer, H. and Reyers, B. (2016). Knowledge co-production and boundary work to promote implementation of conservation plans. Conservation Biology, 30(1), pp.176-188.

Neves-Graça, K. (2004) Revisiting the tragedy of the commons: Ecological dilemmas of whale watching in the Azores. Human Organization, 63(3), pp.289-300.

Newman, J. (2005) Enter the transformational leader: network governance and the micro-politics of modernization. Sociology, 39(4), pp.717-734.

Nutley, S.M., Powell, A.E., Davies, H.T.O. (2013). What counts as good evidence. Alliance for Useful Evidence, London.

Ntshotsho, P., Prozesky, H.E., Esler, K.J. and Reyers, B. (2015). What drives the use of scientific evidence in decision making? The case of the South African Working for Water program. Biological Conservation, 184, pp.136-144.

Nursey-Bray, M., Marsh, H., Ross, H. (2010) Exploring discourses in environmental decision making: an indigenous hunting case study. Society and Natural Resources, 23, pp. 366-382

Owens, S. (2005) Making a difference? Some perspectives on environmental research and policy. Trans Institute of British Geography, 30, pp.287-292

PACEC (2006) The contribution of deer management to the Scottish economy. [pdf] Available at: http://www.deer-management.co.uk/wp-content/uploads/2014/03/PACEC-REPORT-EXECUTIVESUMMARY.pdf. Accessed: $12^{\text {th }}$ February 2016

Provençal, J., (2011). Extending the reach of research as a public good: Moving beyond the paradox of "zero-sum language games". Public Understanding of Science, 20(1), pp. 101. 
Puente-Rodríguez, D., van Slobbe, E., Lindenbergh, D.E. (2016) Knowledge co-production in practice: Enabling environmental management systems for ports through participatory research in the Dutch Wadden Sea. Environmental Science \& Policy, 55 (3), pp. 456-466

Raptor Persecution Scotland (2015) Shameful catalogue of raptor persecution revealed in RSPB's birdcrime 2014 report. In: Raptor Persecution Scotland. 26 ${ }^{\text {th }}$ November 2015. Available at:

https://raptorpersecutionscotland.wordpress.com/2015/11/26/shameful-catalogue-of-raptorpersecution-revealed-in-rspbs-birdcrime-2014-report/ Accessed: $26^{\text {th }}$ November 2015

Raptor Persecution Scotland (2017) Raptor satellite tag review: the questions being addressed. $26^{\text {th }}$ April 2017. Available at: https://raptorpersecutionscotland.wordpress.com/2017/04/26/raptorsatellite-tag-review-the-questions-being-addressed/Accessed: 15 $5^{\text {th }}$ May 2017

Raymond, C.M., Fazey, I., Reed, M.S., Stringer, L.C., Robinson, G.M. and Evely, A.C. (2010). Integrating local and scientific knowledge for environmental management. Journal of environmental management, 91(8), pp.1766-1777.

Redpath, S.M. and Thirgood, S.J. (eds.) 1997. Birds of prey and red grouse. Stationery Office:

Edinburgh

Redpath, S. and Thirgood, S. (2009) Hen harriers and red grouse: moving towards consensus?. Journal of Applied Ecology, 46(5), pp.961-963.

Redpath, S.M., Amar, A., Smith, A., Thompson, D.B.A. and Thirgood, S. (2010) People and nature in conflict: can we reconcile hen harrier conservation and game management. Species Management: Challenges and Solutions for the 21st Century, pp.335-350.

Redpath, S.M., Young, J., Evely, A., Adams, W.M., Sutherland, W.J., Whitehouse, A., Amar, A., Lambert, R.A., Linnell, J.D., Watt, A. and Gutiérrez, R.J., (2013) Understanding and managing conservation conflicts. Trends in Ecology \& Evolution, 28, pp.100-109.

Redpath, S.M., Bhatia, S. and Young, J. (2015) Tilting at wildlife: reconsidering human wildlife conflict. Oryx, 49(02), pp.222-225.

Rokeach, M. (1968) The role of values in public opinion research. Public Opinion Quarterly, 32(4), pp.547-559. 
Roux, D.J., Rogers, R.H., Biggs, H.C., Ashton, P.J., Sergeant, A. (2006) Bridging the sciencemanagement divide moving from unidirectional knowledge transfer to knowledge interfacing and sharing. Ecology and Society, 11(2), 37

RSPB (2010) The illegal killing of birds of prey in Scotland in 2010. [pdf] Royal Society for the Protection of Birds. Available at:

http://www.scottishraptorstudygroup.org/Persecution\%20Scotland\%202010 [pdf] Accessed: $15^{\text {th }}$ March 2016

RSPB (2011) The illegal killing of birds of prey in Scotland in 2011. [pdf] Royal Society for the Protection of Birds. Available at:

http://www.scottishraptorstudygroup.org/The\%20Illega|\%20Killing\%20of\%20Birds\%20of\%20Prev\%20 in\%20Scotland\%202011[1]. Accessed: $15^{\text {th }}$ March 2016

RSPB (2012) The illegal killing of birds of prey in Scotland in 2012. [pdf] Royal Society for the Protection of Birds. Available at:

http://www.scottishraptorstudygroup.org/The\%20Illega|\%20Killing\%20of\%20Birds\%20of\%20Prey\%20 in\%20Scotland\%202012.pdf. Accessed: 15 ${ }^{\text {th }}$ March 2016

RSPB (2013) The illegal killing of birds of prey in Scotland in 2012. [pdf] Royal Society for the Protection of Birds. Available at:

http://www.scottishraptorstudygroup.org/The\%20Illegal\%20Killing\%20of\%20Birds\%20of\%20Prev\%20 in\%20Scotland\%202012.pdf. Accessed: 15 $5^{\text {th }}$ March 2016

RSPB (2014) The illegal killing of birds of prey in Scotland 1994-2014: A review. [pdf] Royal Society for the Protection of Birds. Available at: <https://www.rspb.org.uk/Images/illegal-killing tcm9411686.pdf> [Accessed 28 March 2016]

Sarewitz, D. (2004) How science makes environmental controversies worse. Environmental science \& policy, 7(5), pp.385-403.

Sarewitz, D. (2011) Does climate change knowledge really matter? Wiley Interdisciplinary Reviews: Climate Change, 2 (4), pp. 475-481

Schwedes, O., Kettner, S. and Tiedtke, B. (2013) E-mobility in Germany: White hope for a sustainable development or Fig leaf for particular interests?. Environmental science \& policy, 30, pp.72-80.

Scottish Government (2010) The Economic Impact of Wildlife Tourism in Scotland. [pdf] Available at: https://www.gov.scot/Publications/2010/05/12164456/11. Accessed: 14 ${ }^{\text {th }}$ February 2016 
Skogen, K., (2003) Adapting adaptive management to a cultural understanding of land use conflicts. Society \&Natural Resources, 16(5), pp.435-450.

Skogen, K., Krange, O., Figari, H. eds. (2017) Wolf conflicts: a sociological study. Berghan Books: New York.

Strauss, A.L., and Corbin, J.M. (1998) Basics of qualitative research: techniques and procedures for developing grounded theory. Sage Publications, London

Tennøy, A., (2012). How and Why Planners Make Plans, Which If Implemented, Cause Growth in Traffic Volumes. Explanations related to the expert knowledge, the planners and the plan-making processes (PhD thesis)

Tennøy, A., Hansson, L., Lissandrello, E. and Næss, P. (2016). How planners' use and non-use of expert knowledge affect the goal achievement potential of plans: Experiences from strategic land-use and transport planning processes in three Scandinavian cities. Progress in Planning, 109, pp.1-32.

Thirgood, S. and Redpath, S. (1997) Red grouse and their predators. Nature, 390: pp. 547.

Thirgood, S.J., Redpath, S., Rothery, P., Aebischer, N. (2000) Raptor predation and population limitation in red grouse. Journal of Animal Ecology, 69,pp. 504-516.

Thirgood, S. and Redpath, S. (2008) Hen harriers and red grouse: science, politics and human-wildlife conflict. Journal of Applied Ecology, 45(5), pp.1550-1554.

Thompson, C., McCaughan, D., Cullum, N., Sheldon, T.A., Mulhall, A. and Thompson, D.R. (2001) The accessibility of research-based knowledge for nurses in United Kingdom acute care settings. Journal of advanced nursing, 36(1), pp.11-22.

Tengö, M., Brondizio, E.S., Elmqvist, T., Malmer, P. and Spierenburg, M., (2014). Connecting diverse knowledge systems for enhanced ecosystem governance: the multiple evidence base approach. Ambio, 43(5), pp.579-591.

Tinch, R., Balian, E., Carss, D., de Blas, D.E., Geamana, N.A., Heink, U., Keune, H., Nesshöver, C., Niemelä, J., Sarkki, S. and Thibon, M. (2018) Science-policy interfaces for biodiversity: dynamic learning environments for successful impact. Biodiversity and Conservation, 27(7), pp.1679-1702. Torres, D.F., Oliveira, E.S, Romulo, R.N.A. (2018) Understanding human-wildlife conflicts and their implications. Ethnozoology, 22, pp.421-445 
Turnhout, E., Hisschemöller, M. and Eijsackers, H. (2008). Science in Wadden Sea policy: from accommodation to advocacy. Environmental science \& policy, 11(3), pp.227-239.

Turnhout, E., Bloomfield, B., Hulme, M., Vogel, J. and Wynne, B. (2012) Conservation policy: listen to the voices of experience. Nature, 488(7412), p.454

Troumbis, A.Y., Vasios, G.K. and Hatziantoniou, M.N. (2018) Multiple conservation criteria, discursive conflicts and stakeholder preferences in the era of ecological modernization. Biodiversity and Conservation, pp.1-18.

Turnpenny, J., Russel, D., Jordan, A. (2014) "The challenge of embedding an ecosystems services use in ecosystems services policy" Environment and Planning C: Government and Policy, 32, pp. 229246

Veríssimo, D. and Campbell, B. (2015) Understanding stakeholder conflict between conservation and hunting in Malta. Biological Conservation, 191, pp.812-818.

Verma, A., Van der Wal, R. and Fischer, A. (2017) New Technological Interventions in Conservation Conflicts: Countering Emotions and Contested Knowledge. Human Ecology, 45(5), pp.683-695.

Von Essen, E. and Hansen, H.P. (2015) How stakeholder co-management reproduces conservation conflicts: Revealing rationality problems in Swedish wolf conservation. Conservation and Society, 13(4), p.332.

Watts, R. and Maddison, J. (2012). The role of media actors in reframing the media discourse in the decision to reject relicensing the Vermont Yankee nuclear power plant. Journal of Environmental Studies and Sciences, 2(2), pp.131-142.

Waylen, K.A. and Young, J. (2014) Expectations and experiences of diverse forms of knowledge use: the case of the UK National Ecosystem Assessment. Environment and Planning C: Government and Policy, 32(2), pp.229-246.

Weiss, C.H. (1979) The many meanings of research utilization. Public administration review, 39(5), pp.426-431.

Weingart, P. (1999) Scientific expertise and political accountability: paradoxes of science in politics. Science and Public Policy, 26 (3), pp. 151-161

Wesselink, A. (2009) The emergence of interdisciplinary knowledge in problem-focused research. Area, 41(4), pp.404-413. 
Wesselink, A., Buchanan, K.S., Georgiadou, Y. and Turnhout, E., (2013) Technical knowledge, discursive spaces and politics at the science-policy interface. Environmental Science \& Policy, 30, pp.1-9.

Wesselink, A., Colebatch, H. and Pearce, W., (2014). Evidence and policy: discourses, meanings and practices. Policy Sciences, 47(4), pp.339-344.

Whitfield, D.P., McLeod, D.R., Watson, J., Fielding, A.H. and Haworth, P.F. (2003) The association of grouse moor in Scotland with the illegal use of poisons to control predators. Biological Conservation, 114(2), pp.157-163.

Wiener, Y. (1988) Forms of Value Systems: A Focus on Organisational Effectiveness and Cultural Change and Maintenance. The Academy of Management Review. 13 (4), pp. 534-545

Woodroffe, R., Thirgood, S. and Rabinowitz, A. eds., (2005) People and wildlife, conflict or coexistence? (No. 9). Cambridge University Press.

Yearley, S. (1995) From one dependency to another: the political economy of science policy in the Irish Republic in the second half of the twentieth century. Science, technology, \& human values, 20(2), pp.171-196.

Young, J.C., Waylen, K.A., Sarkki, S., Albon, S., Bainbridge, I., Balian, E., Davidson, J., Edwards, D., Fairley, R., Margerison, C. and McCracken, D. (2014) Improving the science-policy dialogue to meet the challenges of biodiversity conservation: having conversations rather than talking at oneanother. Biodiversity and Conservation, 23(2), pp.387-404.

Young, J. C., Thompson, D. B. A., Moore, P., MacGugan, A., Watt, A. and Redpath, S. M. (2016a) A conflict management tool for conservation agencies. Journal of applied ecology, 53: 705-71 Young, J., Searle, K., Butler, A., Simmons., P., Watt, A.D., Jordan., A. (2016b) The Rolf of Trust in Conservation Conflicts. Biological Conservation, 195, 196-202 
Themes obtained from a thematic analysis of 324 news articles, their abbreviations (in brackets) and detailed descriptions of the content of the articles that fell under these themes. Thematic analysis performed on 324 news articles regarding issues related to the conflict around raptor conservation and grouse shooting in Scotland. Articles authored by six organisations: RSPB, SRSG, SNH, GWCT, SGA and SLE.

\begin{tabular}{|c|c|}
\hline THEME NAME & THEME DESCRIPTION \\
\hline Illegal killing (IA) & $\begin{array}{l}\text { Articles referring to the death or injury of } \\
\text { specifically a raptor, or multiple raptors, } \\
\text { through illegal acts such as poisoning, shooting } \\
\text { and nest disturbance }\end{array}$ \\
\hline Wildlife Crime (WC) & $\begin{array}{l}\text { Articles denoting forms of wildlife crime other } \\
\text { than illegal killing of raptors e.g. setting of } \\
\text { snares, illegal crow traps }\end{array}$ \\
\hline Research (RE) & $\begin{array}{l}\text { Referral to research papers, commissioned } \\
\text { report, scientific data, reviews or statistics }\end{array}$ \\
\hline Legislation and Litigation (LL) & $\begin{array}{l}\text { Article discusses a specific law, changes made } \\
\text { to legislation, or law enforcement }\end{array}$ \\
\hline Management (Ma) & $\begin{array}{l}\text { Discussion of a form of management; either } \\
\text { grouse moor management, other forms of land- } \\
\text { use, or wildlife management }\end{array}$ \\
\hline Conservation (Con) & $\begin{array}{l}\text { Stories of conservation success or failures. } \\
\text { Referral to projects, reintroductions and } \\
\text { translocations }\end{array}$ \\
\hline Impacts (Im) & $\begin{array}{l}\text { Articles discussing the impacts of birds of prey } \\
\text { on gamebirds, livestock and/or other species; } \\
\text { impacts on the economics of grouse moors; or } \\
\text { the impacts of grouse moor management on } \\
\text { birds of prey, other species, and the } \\
\text { environment }\end{array}$ \\
\hline Public Engagement (PE) & $\begin{array}{l}\text { Descriptions of public events, invitations to } \\
\text { activities and competitions, calls for funding or } \\
\text { information }\end{array}$ \\
\hline Other Actors (OA) & $\begin{array}{l}\text { Articles discussing the actions, motives or } \\
\text { claims of other stakeholders. Can be direct } \\
\text { quotes, or indirect references. }\end{array}$ \\
\hline
\end{tabular}


Aarts, J., Östman, J.O. and Verschueren, J. (2011) Corpus analysis. Pragmatics in Practice, 9, p.118.

Allen, T.F.H., Tainter, J.A., Pires, J.C. and Hoekstra, T.W. (2001) Dragnet Ecology—"Just the Facts, Ma'am": The Privilege of Science in a Postmodern World: Science of intrinsic quality needs narratives with explicit values - not just facts-particularly as it faces multiple-level complexity in advising on environmental policy, such as planning for energy futures. BioScience, 51(6), pp.475-485.

Ainsworth, G., Calladine, J., Martay, B., Park, K., Redpath, S., Wernham, C., Wilson, M. \& Young, J. (2016) Understanding Predation. A review bringing together natural science and local knowledge of recent wild bird population changes and their drivers in Scotland. [pdf] Moorland Forum. Available at: https://s3-eu-west-1.amazonaws.com/jotter2.files/5055073?response-contenttype=application\%2Fpdf\&response-content-disposition=inline\%3Bfilename\%3D160205up report.pdf\&X-Amz-Content-Sha256=UNSIGNED-PAYLOAD\&X-Amz-Algorithm=AWS4-HMACSHA256\&X-Amz-Credential=AKIAIH4MJHC24RK4EHAA\%2F20180312\%2Feu-west1\%2Fs3\%2Faws4 request\&X-Amz-Date $=20180312 T 124437 Z \& X$-Amz-SignedHeaders=host\&X-AmzExpires $=3000 \& X-A m z-$ Signature=bc088377ea73403f623ddc4111317b68444002cec3cfedaab1f3acf8dad05d29 Accessed $12^{\text {th }}$ March 2018

Amar, A., Davison, M., Downing, S., Grimshaw, T., Pickford, T. and Raw, D. (2012) Linking nest histories, remotely sensed land use data and wildlife crime records to explore the impact of grouse moor management on peregrine falcon populations. Biological conservation, 145(1), pp.86-94.

Andersson, P. and Öhman, J. (2016). Logics of business education for sustainability. Environmental Education Research, 22(4), pp.463-479.

Ansell, C. and Gash, A. (2008) Collaborative governance in theory and practice. Journal of public administration, Research and Theory, 18 (4),543-571

Armitage, D., Berkes, F., Dale, A., Kocho-Schellenberg, E. and Patton, E. (2011). Co-management and the co-production of knowledge: learning to adapt in Canada's Arctic. Global Environmental Change, 21(3), pp.995-1004.

Arts, B. and Buizer, M. (2009) Forests, discourses, institutions: A discursive-institutional analysis of global forest governance. Forest policy and economics, 11(5), pp.340-347.

Arts, K., Fischer, A. and van der Wal, R. (2012) Common stories of reintroduction: a discourse analysis of documents supporting animal reintroductions to Scotland. Land Use Policy, 29(4), pp.911-920. 
Avery, M. (2017) Good start! In: Mark Avery. 10 $0^{\text {th }}$ October 2017 [viewed $10^{\text {th }}$ October 2017]. Available from: https://markavery.info/2017/10/10/good-start/

Balmer, D.E., Gillings, S., Caffrey, B., Swann, R.L., Downie, I.S. and Fuller, R.J. (2013). Bird Atlas 200711: The Breeding and Wintering Birds of Britain and Ireland. British Trust for Ornithology, Thetford.

Barnes, M., Newman, J., Knops, A. and Sullivan, H., 2003. Constituting 'the public'in public participation. Public administration, 81(2), pp.379-399.

Bartesaghi, M. \& Castor, T. (2008) Social Construction in Communication Re-Constituting the Conversation. Annals of the International Communication Association, 32 (1), 1-39

Bateson, G. (1935) Culture Contact and Schismogenesis. Man, 35.

Baxter, L. A., \& Montgomery, B. M. (1996). Relating: Dialogues and dialectics. New York: Guilford Press.

Benford, R.D. and Snow, D.A., (2000) Framing processes and social movements: An overview and assessment. Annual review of sociology, 26(1), pp.611-639.

Benjaminsen, T.A. and Svarstad, H. (2010) The death of an elephant: Conservation discourses versus practices in Africa. In Forum for development studies, 37 (3) pp. 385-408

Berkes, F., (2009). Evolution of co-management: role of knowledge generation, bridging organizations and social learning. Journal of environmental management, 90(5), pp.1692-1702.

Bingham, N., (2003). Introduction. In: Bingham, N., Blowers, A.,Belshaw, C. (Eds.), Contested Environments. Wiley in Association with the Open University, Chichester

Blaikie, P. (2001) Is policy reform pure nostalgia? A Himalayan illustration. In: Berkeley Workshop on Environmental Politics Working Paper WP 01-9. Berkeley, California: Insititute of International Studies, University of California

Blekesaune, A. (1997). Rovviltdiskursen: En analyse av ideologisk baserte skillelinjer. Trondheim Senter for bygdeforskning.

Boswell, C. (2008). The political functions of expert knowledge: knowledge and legitimation in European Union immigration policy. Journal of European Public Policy, 15(4), pp.471-488. 
Bou-Llusar, C.J. and Segarra-Ciprés, M., (2006). Strategic knowledge transfer and its implications for competitive advantage: an integrative conceptual framework. Journal of knowledge management, 10(4), pp.100-112.

Boyatzis, R.E. (1998) Transforming qualitative information: thematic analysis and code development. Sage, London.

Bozak, N., 2008. Manufactured landscapes. Film Quarterly, 62(2), pp.68-71.

Bracken, L. and Oughton, L. (2013) Making sense of policy: the creative uses of evidence in managing freshwater environments. Environmental Science and Policy, 30 (2013), pp. 10-18

Briggs, S.V. (2006) "Integrating policy and science in natural resources: Why so difficult?" Ecological Management \& Restoration, 7(1) 37-39

Brox, O. (2000) Schismogenesis in the wilderness: the reintroduction of predators in Norwegian forests. Ethnos, 65, pp. 124-1253

Buber, M. (1970). I and thou (W. Kauffman, Trans.). New York: Scribner's.

Buchanan, K.S. (2013) Contested discourses, knowledge, and socio-environmental conflict in Ecuador. Environmental science \& policy, 30, pp.19-25.

Buijs, A.E. (2009) Lay people's images of nature: frameworks of values, beliefs and value orientations, Society and Natural Resources, 22, pp. 417-432

Buijs, A.E., Arts, B.J., Elands, B.H. and Lengkeek, J. (2011) Beyond environmental frames: the social representation and cultural resonance of nature in conflicts over a Dutch woodland. Geoforum, 42(3), pp.329-341.

Buijs, A., Mattijssen, T. and Arts, B. (2014) "The man, the administration and the counter-discourse": An analysis of the sudden turn in Dutch nature conservation policy. Land Use Policy, 38, pp.676-684. Büscher, B. (2016). Nature 2.0: Exploring and theorizing the links between new media and nature conservation. New media \& society, 18(5), pp.726-743.

Butler, J.R.A., Young, J.C., McMyn, I.A.G., Leyshon, B., Graham, I.M., Walker, I., Baxter, J.M., Dodd, J. and Warburton, C., 2015. Evaluating adaptive co-management as conservation conflict resolution: learning from seals and salmon. Journal of environmental management, 160, pp.212-225. 
Carmen, E., Watt, A. and Young, J., (2016) Arguing for biodiversity in practice: a case study from the UK. Biodiversity and Conservation, pp.1-19.

Carragee, K.M. and Roefs, W. (2004) The neglect of power in recent framing research. Journal of communication, 54(2), pp.214-233.

Callon, M., (1999) The role of lay people in the production and dissemination of scientific knowledge. Science, Technology and Society, 4(1), pp.81-94.

Carvalho, A. (2007) Ideological cultures and media discourses on scientific knowledge: re-reading news on climate change. Public Understanding of Science, 16, pp. 223-243

Cash, D.W., Clark, W.C., Alcock, F., Dickson, N.M., Eckley, N., Guston, D.H., Jäger, J. and Mitchell, R.B., 2003. Knowledge systems for sustainable development. Proceedings of the national academy of sciences, 100(14), pp.8086-8091.

Castree, N. (2001) Socializing nature: Theory, practice, and politics. Social nature: Theory, practice, and politics, pp.1-21.

Crate, S.A. and Nuttall, M. (eds) (2016) Anthropology and climate change: from encounters to actions. Routledge.

Crouzat, E., Arpin, I., Brunet, L., Colloff, M.J., Turkelboom, F. and Lavorel, S., 2018. Researchers must be aware of their roles at the interface of ecosystem services science and policy. Ambio, 47(1), pp.97105

Cook, C.N., Mascia, M.B., Schwartz, M.W., Possingham, H.P. and Fuller, R.A. (2013). Achieving conservation science that bridges the knowledge-action boundary. Conservation Biology, 27(4), pp.669-678.

Cowell, R. and Lennon, M., (2014). The utilisation of environmental knowledge in land-use planning: drawing lessons for an ecosystem services approach. Environment and Planning C: Government and Policy, 32(2), pp.263-282

Cullen, L. (2017) RSPB Scotland welcomes wildlife crime report. $8^{\text {th }}$ December 2017. Available at: https://www.rspb.org.uk/about-the-rspb/about-us/media-centre/press-releases/rspb-scotlandwelcomes-wildlife-crime-report/

Cvitanovic, C., Hobday, A.J., van Kerkhoff, L., Wilson, S.K., Dobbs, K. and Marshall, N.A. (2015). Improving knowledge exchange among scientists and decision-makers to facilitate the adaptive 
governance of marine resources: a review of knowledge and research needs. Ocean \& Coastal Management, 112, pp.25-35.

Davoudi, S. (2006) Evidence-based planning: rhetoric and reality. disP-The Planning Review, 42(165), pp.14-24.

Den Besten, W. J., Arts, B., \& Verkooijen, P. (2013). The evolution of REDD +: An analysis of 35 discursive- institutional dynamics. Environmental Science and Policy, 1-9.

Dessai, S., Hulme, M., Lempert, R. and Pielke, R. (2009) Do we need better predictions to adapt to a changing climate?. Eos, Transactions American Geophysical Union, 90(13), pp.111-112.

Dinnie, E., Fischer, A. and Huband, S. (2015). Discursive claims to knowledge: the challenge of delivering public policy objectives through new environmental governance arrangements. Journal of Rural Studies, 37, pp.1-9.

Dunk, T. (2002) Hunting and the politics of identity in Ontario. Capitalism Nature Socialism, 13, pp. 3666

Dunlop, C.A. (2014) "The possible experts: how epistemic communities negotiate barriers to knowledge use in ecosystems services policy. Environment and Planning C: Government and Policy, 32(2), pp.208-228.

Eden, S., Donaldson, A., Walker, G. (2006) Green Groups and Grey Areas: Scientific Boundary-Work, Nongovernmental Organisations, and Environmental Knowledge. Environment and Planning A, 38 (6) pp. 1061-1076

Etheridge, B., Summers, R.W., Green, R.E. (1997) The effects of illegal killing and destruction of nests by humans on the population dynamics of the hen harrier Circus cyaneus in Scotland. Journal of Applied Ecology, 34, pp. 1081-1105

Fazey, I., Fazey, J.A., Salisbury, J.G., Lindenmayer, D.B. and Dovers, S. (2006). The nature and role of experiential knowledge for environmental conservation. Environmental conservation, 33(1), pp.1-10. Fielding, A., Haworth, P., Whitfield, P., McLeod, D. \& Riley, H. (2011) A Conservation Framework for Hen Harriers in the United Kingdom. JNCC Report 441. Joint Nature Conservation Committee, Peterborough.

Fielding, A.H. and Haworth, P.F. (2014) Golden eagles in the south of Scotland: an overview. Scottish Natural Heritage Commissioned Report No. 626. 
Fischer, F. (1998) Beyond empiricism: policy inquiry in post positivist perspective. Policy studies journal, 26(1), pp.129-146.

Fischer, A. and Van Der Wal, R. (2007) Invasive plant suppresses charismatic seabird-the construction of attitudes towards biodiversity management options. Biological Conservation, 135(2), pp.256-267.

Garrett, J.L. and Islam, Y. (eds) 1998. Policy Research and the Policy Process: Do the twain ever meet? In: Gatekeeper Series-Sustainable Agriculture Programme, International Institute for Environment and Development (United Kingdom).

Gamson, W. (2005). The Public Opinion Quarterly, 69(2), 324-326

Greenhalgh, T. and Wieringa, S. (2011). Is it time to drop the 'knowledge translation' metaphor? A critical literature review. Journal of the Royal Society of Medicine, 104(12), pp.501-509.

GWCT (2007) Singing fields: why gamekeeping helps birds in the countryside. [pdf] available at: https://www.gwct.org.uk/media/249264/singing fields report.pdf. Accessed: 12 ${ }^{\text {th }}$ February 2016

GWCT (2014) Big Farmland Bird Count Results. [pdf] Available at:

https://www.gwct.org.uk/media/388634/Big-Farmland-Bird-Fact-Sheet.pdf. Accessed: 15 $5^{\text {th }}$ March 2015

Haines-Young, R. and Potschin, M. (2014). The ecosystem approach as a framework for understanding knowledge utilisation. Environment and Planning C: Government and Policy, 32(2), pp.301-319.

Hajer, M. and Versteeg, W. (2005) A decade of discourse analysis of environmental politics: achievements, challenges, perspectives. Journal of environmental policy \& planning, 7(3), pp.175-184. Hajer, M.A. (ed) (1995) The politics of environmental discourse: ecological modernization and the policy process (p. 40). Oxford: Clarendon Press.

Hajer, M.A., van den Brink, M. and Metze, T. (2006) Doing discourse analysis: coalitions, practices, meaning. Netherlands geographical studies (ISSN 0169-4839), (344).

Hulme, D., Savoia, A. and Sen, K. (2015) Governance as a Global Development Goal? Setting, Measuring and Monitoring the Post-2015 Development Agenda. Global Policy, 6(2), pp.85-96.

Hodgson, I.D., Redpath, S.M., Fischer, A., Young, J.C. (2018a) A conflict with wings: understanding the narratives, relationships and hierarchies of conflicts over raptors and red grouse in Scotland. PhD thesis, University of Aberdeen. 
Hodgson, I.D., Redpath, S.M., Fischer, A., Young, J.C. (2018b) Fighting Talk: the use of discourse by organisations in the conflict over raptors in Scotland. Land Use Policy, 77, pp.332-343.

Hoffmann, D. \& Rohe, H. (2015): Excursion to Glenogil estate - Scotland. 26. IV. - 30. IV.

Hsieh, H.F. and Shannon, S.E. (2005) Three approaches to qualitative content analysis. Qualitative health research, 15(9), pp.1277-1288.

Idrissou, L., Aarts, N., van Paassen, A. and Leeuwis, C. (2011) The discursive construction of conflict in participatory forest management: the case of the Agoua forest restoration in Benin. Conservation and society, 9(2), p.119.

Iyengar, S., (1990) Framing responsibility for political issues: The case of poverty. Political behavior, 12(1), pp.19-40.

Jasanoff S. (1998) NGOs and the Environment: from Knowledge to Action. In: Weiss T.G. (eds) Beyond UN Subcontracting. International Political Economy Series. Palgrave Macmillan, London Jasanoff, S. (2003). Technologies of humility: citizen participation in governing science. Minerva, 41(3), pp.223-244.

Jasanoff, S. (ed.) 2004. States of knowledge: the co-production of science and the social order. Routledge.

Layton, M. (2015) New gamebird figures challenge RSPB claims. $9^{\text {th }}$ October 2015. In: Shooting UK News. Available at: https://www.shootinguk.co.uk/shooting/game-shooting/pheasant-shooting/newgamebird-figures-challenge-rspb-claims-47753. Accessed: 12 $2^{\text {th }}$ January 2017

Lemos, M.C., Kirchhoff, C.J. and Ramprasad, V. (2012). Narrowing the climate information usability gap. Nature Climate Change, 2(11), pp.789-794.

Lemos, M.C. and Morehouse, B.J. (2004), "The co-production of science and policy in integrated climate assessments". Global Environmental Change, 15(1), pp.57-68

Lindsey, P.A., Balme, G.A., Funston, P.J., Henschel, P.H. and Hunter, L.T., 2016. Life after Cecil: channelling global outrage into funding for conservation in Africa. Conservation Letters, 9(4), pp.296301.

Linell, P. and Marková, I. (eds.) 2014. Dialogical approaches to trust in communication. Information Age Publishing: Charlotte, NC. 
Lovegrove, R., (2007) Silent fields: the long decline of a nation's wildlife. Oxford University Press, UK

Lüchtrath, A. and Schraml, U. (2015) The missing lynx-understanding hunters' opposition to large carnivores. Wildlife Biology, 2(21), pp.110-119.

Lunstrum, E., (2017) Feed them to the lions: Conservation violence goes online. Geoforum, 79, pp.134-143.

Kinzig, A.P., Pacala, S.W. and Tilman, D. eds. (2001) The functional consequences of biodiversity: empirical progress and theoretical extensions (Vol. 33). Princeton University Press.

Krange, O. and Skogen, K. (2010). The Hammertown mechanism. Cultural resistance and political marginalization. Transitions in Marginal Zones in the Age of Globalization: Case Studies from the North and South, 223, p.248.

Krizek, K., Forysth, A. and Slotterback, C.S., 2009. Is there a role for evidence-based practice in urban planning and policy?. Planning Theory \& Practice, 10(4), pp.459-478.

Madden, F. and McQuinn, B., (2014) Conservation's blind spot: The case for conflict transformation in wildlife conservation. Biological Conservation, 178, pp.97-106.

Marshall, K., White, R. and Fischer, A. (2007) Conflicts between humans over wildlife management: on the diversity of stakeholder attitudes and implications for conflict management. Biodiversity and Conservation, 16(11), pp.3129-3146.

McKenzie, E., Posner, S., Tillmann, P., Bernhardt, J.R., Howard, K. and Rosenthal, A., (2014).

Understanding the use of ecosystem service knowledge in decision making: lessons from international experiences of spatial planning. Environment and Planning C: Government and Policy, 32(2), pp.320340.

Miall, H. (2004) Conflict transformation: A multi-dimensional task. In: Austin, A., Fischer, M., Ropers, N. (eds.) Transforming Ethnopolitical Conflict (pp. 67-89). VS Verlag für Sozialwissenschaften.

Næss, P., Hansson, L., Richardson, T., Tennøy, A. (2013) Knowledge-based land use and transport planning? Consistency and gap between "state-of-the-art" knowledge and knowledge claims in planning documents in three Scandinavian city regions. Planning Theory \& Practice, 14 (4), pp. 470491

Negev, N. Teschner, M. (2013) Rethinking the relationship between technical and local knowledge: towards multiple types of knowledge. Environmental Science and Policy, 30, pp. 50-59 
Nel, J.L., Roux, D.J., Driver, A., Hill, L., Maherry, A.C., Snaddon, K., Petersen, C.R., Smith-Adao, L.B., Deventer, H. and Reyers, B. (2016). Knowledge co-production and boundary work to promote implementation of conservation plans. Conservation Biology, 30(1), pp.176-188.

Neves-Graça, K. (2004) Revisiting the tragedy of the commons: Ecological dilemmas of whale watching in the Azores. Human Organization, 63(3), pp.289-300.

Newman, J. (2005) Enter the transformational leader: network governance and the micro-politics of modernization. Sociology, 39(4), pp.717-734.

Nutley, S.M., Powell, A.E., Davies, H.T.O. (2013). What counts as good evidence. Alliance for Useful Evidence, London.

Ntshotsho, P., Prozesky, H.E., Esler, K.J. and Reyers, B. (2015). What drives the use of scientific evidence in decision making? The case of the South African Working for Water program. Biological Conservation, 184, pp.136-144.

Nursey-Bray, M., Marsh, H., Ross, H. (2010) Exploring discourses in environmental decision making: an indigenous hunting case study. Society and Natural Resources, 23, pp. 366-382

Owens, S. (2005) Making a difference? Some perspectives on environmental research and policy. Trans Institute of British Geography, 30, pp.287-292

PACEC (2006) The contribution of deer management to the Scottish economy. [pdf] Available at: http://www.deer-management.co.uk/wp-content/uploads/2014/03/PACEC-REPORT-EXECUTIVESUMMARY.pdf. Accessed: $12^{\text {th }}$ February 2016

Provençal, J., (2011). Extending the reach of research as a public good: Moving beyond the paradox of "zero-sum language games". Public Understanding of Science, 20(1), pp. 101.

Puente-Rodríguez, D., van Slobbe, E., Lindenbergh, D.E. (2016) Knowledge co-production in practice: Enabling environmental management systems for ports through participatory research in the Dutch Wadden Sea. Environmental Science \& Policy, 55 (3), pp. 456-466

Raptor Persecution Scotland (2015) Shameful catalogue of raptor persecution revealed in RSPB's birdcrime 2014 report. In: Raptor Persecution Scotland. 26 ${ }^{\text {th }}$ November 2015. Available at: https://raptorpersecutionscotland.wordpress.com/2015/11/26/shameful-catalogue-of-raptorpersecution-revealed-in-rspbs-birdcrime-2014-report/ Accessed: $26^{\text {th }}$ November 2015 
Raptor Persecution Scotland (2017) Raptor satellite tag review: the questions being addressed. $26^{\text {th }}$ April 2017. Available at: https://raptorpersecutionscotland.wordpress.com/2017/04/26/raptorsatellite-tag-review-the-questions-being-addressed/Accessed: 15 ${ }^{\text {th }}$ May 2017

Raymond, C.M., Fazey, I., Reed, M.S., Stringer, L.C., Robinson, G.M. and Evely, A.C. (2010). Integrating local and scientific knowledge for environmental management. Journal of environmental management, 91(8), pp.1766-1777.

Redpath, S.M., Amar, A., Smith, A., Thompson, D.B.A. and Thirgood, S. (2010) People and nature in conflict: can we reconcile hen harrier conservation and game management. Species Management: Challenges and Solutions for the 21st Century, pp.335-350.

Redpath, S.M., Young, J., Evely, A., Adams, W.M., Sutherland, W.J., Whitehouse, A., Amar, A., Lambert, R.A., Linnell, J.D., Watt, A. and Gutiérrez, R.J., (2013) Understanding and managing conservation conflicts. Trends in Ecology \& Evolution, 28, pp.100-109.

Redpath, S.M., Bhatia, S. and Young, J. (2015) Tilting at wildlife: reconsidering human wildlife conflict. Oryx, 49(02), pp.222-225.

Rokeach, M. (1968) The role of values in public opinion research. Public Opinion Quarterly, 32(4), pp.547-559.

Roux, D.J., Rogers, R.H., Biggs, H.C., Ashton, P.J., Sergeant, A. (2006) Bridging the sciencemanagement divide moving from unidirectional knowledge transfer to knowledge interfacing and sharing. Ecology and Society, 11(2), 37

RSPB (2010) The illegal killing of birds of prey in Scotland in 2010. [pdf] Royal Society for the Protection of Birds. Available at:

http://www.scottishraptorstudygroup.org/Persecution\%20Scotland\%202010 [pdf] Accessed: $15^{\text {th }}$ March 2016

RSPB (2011) The illegal killing of birds of prey in Scotland in 2011. [pdf] Royal Society for the Protection of Birds. Available at:

http://www.scottishraptorstudygroup.org/The\%20Illega|\%20Killing\%20of\%20Birds\%20of\%20Prey\%20 in\%20Scotland\%202011[1]. Accessed: 15 ${ }^{\text {th }}$ March 2016

RSPB (2012) The illegal killing of birds of prey in Scotland in 2012. [pdf] Royal Society for the Protection of Birds. Available at: 
http://www.scottishraptorstudygroup.org/The\%20Illegal\%20Killing\%20of\%20Birds\%20of\%20Prey\%2 0in\%20Scotland\%202012.pdf. Accessed: $15^{\text {th }}$ March 2016

RSPB (2013) The illegal killing of birds of prey in Scotland in 2012. [pdf] Royal Society for the Protection of Birds. Available at:

http://www.scottishraptorstudygroup.org/The\%20Illegal\%20Killing\%20of\%20Birds\%20of\%20Prey\%2 0in\%20Scotland\%202012.pdf. Accessed: $15^{\text {th }}$ March 2016

RSPB (2014) The illegal killing of birds of prey in Scotland 1994-2014: A review. [pdf] Royal Society for the Protection of Birds. Available at: <https://www.rspb.org.uk/Images/illegal-killing tcm9-

411686.pdf> [Accessed 28 March 2016]

Saarikoski, H., Raitio, K. and Barry, J. (2013) Understanding 'successful' conflict resolution: policy regime changes and new interactive arenas in the Great Bear Rainforest. Land Use Policy, 32, pp.271280.

Saarikoski, M., Warne, T., Kaila, P. and Leino-Kilpi, H. (2009) The role of the nurse teacher in clinical practice: an empirical study of Finnish student nurse experiences. Nurse Education Today, 29(6), pp.595-600.

Sarewitz, D. (2011) Does climate change knowledge really matter? Wiley Interdisciplinary Reviews: Climate Change, 2 (4), pp. 475-481

Schmidt, V.A. (2010). Taking ideas and discourse seriously: explaining change through discursive institutionalism as the fourth 'new institutionalism'. European political science review, 2(1), pp.1-25.

Schwedes, O., Kettner, S. and Tiedtke, B. (2013) E-mobility in Germany: White hope for a sustainable development or Fig leaf for particular interests?. Environmental science \& policy, 30, pp.72-80.

Scottish Government (2010) The Economic Impact of Wildlife Tourism in Scotland. [pdf] Available at: https://www.gov.scot/Publications/2010/05/12164456/11. Accessed: $14^{\text {th }}$ February 2016

Shotter, J. (1993). Cultural politics of everyday life: Social constructionism, rhetoric and knowing of the third kind. Toronto, Canada: University of Toronto Press.

Skogen, K., (2003) Adapting adaptive management to a cultural understanding of land use conflicts. Society \&Natural Resources, 16(5), pp.435-450.

Skogen, K., Krange, O., Figari, H. (eds) 2017. Wolf conflicts: a sociological study. Berghan Books: New York. 
Stone, D. (1989) 'Causal Stories and the Formation of Policy Agendas', Political Science Quarterly 104(2): 281-300

Strauss, A.L., Corbin, J.M. (1998) Basics of qualitative research: techniques and procedures for developing grounded theory. Sage Publications, London Tennøy, A., (2012). How and Why Planners Make Plans, Which If Implemented, Cause Growth in Traffic Volumes. Explanations related to the expert knowledge, the planners and the plan-making processes (PhD thesis)

Tennøy, A., Hansson, L., Lissandrello, E. and Næss, P. (2016). How planners' use and non-use of expert knowledge affect the goal achievement potential of plans: Experiences from strategic land-use and transport planning processes in three Scandinavian cities. Progress in Planning, 109, pp.1-32.

Thirgood, S. and Redpath, S. (2008) Hen harriers and red grouse: science, politics and human-wildlife conflict. Journal of Applied Ecology, 45(5), pp.1550-1554.

Thirgood, S., Redpath, S., Newton, I. \& Hudson, P. (2000) Raptors and red grouse: conservation conflicts and management solutions.Conservation Biology, 14, 95-104.

Thompson, C., McCaughan, D., Cullum, N., Sheldon, T.A., Mulhall, A. and Thompson, D.R. (2001) The accessibility of research-based knowledge for nurses in United Kingdom acute care settings. Journal of advanced nursing, 36(1), pp.11-22.

Thompson, P.S., Amar, A., Hoccom, D.G., Knott, J. and Wilson, J.D. (2009) Resolving the conflict between driven-grouse shooting and conservation of hen harriers. Journal of Applied Ecology, 46(5), pp.950-954.

Thompson, P.S., Douglas, D.J., Hoccom, D.G., Knott, J., Roos, S. and Wilson, J.D. (2016) Environmental impacts of high-output driven shooting of Red Grouse Lagopus lagopus scotica. Ibis, 158(2), pp.446452.

Tengö, M., Brondizio, E.S., Elmqvist, T., Malmer, P. and Spierenburg, M., (2014). Connecting diverse knowledge systems for enhanced ecosystem governance: the multiple evidence base approach. Ambio, 43(5), pp.579-591.

Tinch, R., Balian, E., Carss, D., de Blas, D.E., Geamana, N.A., Heink, U., Keune, H., Nesshöver, C., Niemelä, J., Sarkki, S. and Thibon, M. (2018) Science-policy interfaces for biodiversity: dynamic learning environments for successful impact. Biodiversity and Conservation, 27(7), pp.1679-1702. 
Torres, D.F., Oliveira, E.S, Romulo, R.N.A. (2018) Understanding human-wildlife conflicts and their implications. Ethnozoology, 22, pp.421-445

Turnhout, E., Hisschemöller, M. and Eijsackers, H. (2008). Science in Wadden Sea policy: from accommodation to advocacy. Environmental science \& policy, 11(3), pp.227-239.

Troumbis, A.Y., Vasios, G.K. and Hatziantoniou, M.N. (2018) Multiple conservation criteria, discursive conflicts and stakeholder preferences in the era of ecological modernization. Biodiversity and Conservation, pp.1-18.

Turnpenny, J., Russel, D., Jordan, A. (2014) "The challenge of embedding an ecosystems services use in ecosystems services policy" Environment and Planning C: Government and Policy, 32, pp. 229246

Veríssimo, D. and Campbell, B. (2015) Understanding stakeholder conflict between conservation and hunting in Malta. Biological Conservation, 191, pp.812-818.

Verma, A., Van der Wal, R. and Fischer, A. (2017) New Technological Interventions in Conservation Conflicts: Countering Emotions and Contested Knowledge. Human Ecology, 45(5), pp.683-695.

Von Essen, E. and Hansen, H.P. (2015) How stakeholder co-management reproduces conservation conflicts: Revealing rationality problems in Swedish wolf conservation. Conservation and Society, 13(4), p.332.

Watts, R. and Maddison, J. (2012). The role of media actors in reframing the media discourse in the decision to reject relicensing the Vermont Yankee nuclear power plant. Journal of Environmental Studies and Sciences, 2(2), pp.131-142.

Waylen, K.A. and Young, J. (2014) Expectations and experiences of diverse forms of knowledge use: the case of the UK National Ecosystem Assessment. Environment and Planning C: Government and Policy, 32(2), pp.229-246.

Weiss, C.H. (1979) The many meanings of research utilization. Public administration review, 39(5), pp.426-431.

Weingart, P. (1999) Scientific expertise and political accountability: paradoxes of science in politics. Science and Public Policy, 26 (3), pp. 151-161

Wesselink, A., (2009) The emergence of interdisciplinary knowledge in problem-focused research. Area, 41(4), pp.404-413. 
Wesselink, A., Buchanan, K.S., Georgiadou, Y. and Turnhout, E., (2013) Technical knowledge, discursive spaces and politics at the science-policy interface. Environmental Science \& Policy, 30, pp.1-9.

Wesselink, A., Colebatch, H. and Pearce, W., (2014). Evidence and policy: discourses, meanings and practices. Policy Sciences, 47(4), pp.339-344.

Whitfield, D.P., McLeod, D.R., Watson, J., Fielding, A.H. and Haworth, P.F. (2003) The association of grouse moor in Scotland with the illegal use of poisons to control predators. Biological Conservation, 114(2), pp.157-163.

Wiener, Y. (1988) Forms of Value Systems: A Focus on Organisational Effectiveness and Cultural Change and Maintenance. The Academy of Management Review. 13 (4), pp. 534-545

Woodroffe, R., Thirgood, S. and Rabinowitz, A. eds., (2005) People and wildlife, conflict or coexistence? (No. 9). Cambridge University Press.

Yearley, S. (1995) From one dependency to another: the political economy of science policy in the Irish Republic in the second half of the twentieth century. Science, technology, \& human values, 20(2), pp.171-196.

Young, J.C., Waylen, K.A., Sarkki, S., Albon, S., Bainbridge, I., Balian, E., Davidson, J., Edwards, D., Fairley, R., Margerison, C. and McCracken, D. (2014) Improving the science-policy dialogue to meet the challenges of biodiversity conservation: having conversations rather than talking at oneanother. Biodiversity and Conservation, 23(2), pp.387-404.

Young, J. C., Thompson, D. B. A., Moore, P., MacGugan, A., Watt, A. and Redpath, S. M. (2016a) A conflict management tool for conservation agencies. Journal of applied ecology, 53: 705-71 Young, J., Searle, K., Butler, A., Simmons., P., Watt, A.D., Jordan., A. (2016b) The Rolf of Trust in Conservation Conflicts. Biological Conservation, 195, 196-202

Yusran, Y., Sahide, M.A.K., Supratman, S., Sabar, A., Krott, M. and Giessen, L. (2017) The empirical visibility of land use conflicts: From latent to manifest conflict through law enforcement in a national park in Indonesia. Land Use Policy, 62, pp.302-315.

Zachrisson, A. and Lindahl, K.B. (2013) Conflict resolution through collaboration: Preconditions and limitations in forest and nature conservation controversies. Forest policy and economics, 33, pp.39-46. 
